\title{
Changing surface-atmosphere energy exchange and refreezing capacity of the lower accumulation area, West Greenland
}

\author{
C. Charalampidis ${ }^{1,2}$, D. van As ${ }^{1}$, J. E. Box ${ }^{1}$, M. R. van den Broeke ${ }^{3}$, W. T. Colgan ${ }^{1,4}$, S. H. Doyle ${ }^{5}$, A. L. Hubbard ${ }^{6}$, \\ M. MacFerrin ${ }^{7}$, H. Machguth ${ }^{1,8}$, and C. J. P. P. Smeets ${ }^{3}$ \\ ${ }^{1}$ Geological Survey of Denmark and Greenland (GEUS), Øster Voldgade 10, 1350 Copenhagen K, Denmark \\ ${ }^{2}$ Department of Earth Sciences, Uppsala University, Villavägen 16, 75236 Uppsala, Sweden \\ ${ }^{3}$ Institute for Marine and Atmospheric research (IMAU), Utrecht University, P.O. Box 80005, \\ 3508TA Utrecht, the Netherlands \\ ${ }^{4}$ Department of Earth and Space Sciences and Engineering, York University, 4700 Keele Street, M3J 1P3, Toronto, Canada \\ ${ }^{5}$ Centre for Glaciology, Department of Geography and Earth Sciences, Aberystwyth University, Aberystwyth, SY23 3DB, UK \\ ${ }^{6}$ Centre for Arctic Gas Hydrate, Environment and Climate, Department of Geology, University of Troms $\varnothing$, Dramsveien 201, \\ 9037 Troms $\varnothing$, Norway \\ ${ }^{7}$ Cooperative Institute for Research in Environmental Sciences (CIRES), 216 UCB, University of Colorado Boulder, \\ Boulder, CO 80309, USA \\ ${ }^{8}$ Arctic Technology Centre (ARTEK), Technical University of Denmark, Brovej, byg. 118, 2800 Kgs. Lyngby, Denmark
}

Correspondence to: C. Charalampidis (cc@geus.dk)

Received: 19 March 2015 - Published in The Cryosphere Discuss.: 27 May 2015

Revised: 18 October 2015 - Accepted: 25 October 2015 - Published: 18 November 2015

\begin{abstract}
We present 5 years (2009-2013) of automatic weather station measurements from the lower accumulation area (1840 ma.s.1. - above sea level) of the Greenland ice sheet in the Kangerlussuaq region. Here, the summers of 2010 and 2012 were both exceptionally warm, but only 2012 resulted in a strongly negative surface mass budget (SMB) and surface meltwater run-off. The observed run-off was due to a large ice fraction in the upper $10 \mathrm{~m}$ of firn that prevented meltwater from percolating to available pore volume below. Analysis reveals an anomalously low 2012 summer-averaged albedo of 0.71 (typically $\sim 0.78$ ), as meltwater was present at the ice sheet surface. Consequently, during the 2012 melt season, the ice sheet surface absorbed $28 \%\left(213 \mathrm{MJ} \mathrm{m}^{-2}\right)$ more solar radiation than the average of all other years.

A surface energy balance model is used to evaluate the seasonal and interannual variability of all surface energy fluxes. The model reproduces the observed melt rates as well as the SMB for each season. A sensitivity analysis reveals that $71 \%$ of the additional solar radiation in 2012 was used for melt, corresponding to $36 \%(0.64 \mathrm{~m})$ of the 2012 surface lowering. The remaining $64 \%(1.14 \mathrm{~m})$ of surface lowering resulted from high atmospheric temperatures, up to a $+2.6^{\circ} \mathrm{C}$
\end{abstract}

daily average, indicating that 2012 would have been a negative SMB year at this site even without the melt-albedo feedback.

Longer time series of SMB, regional temperature, and remotely sensed albedo (MODIS) show that 2012 was the first strongly negative SMB year, with the lowest albedo, at this elevation on record. The warm conditions of recent years have resulted in enhanced melt and reduction of the refreezing capacity in the lower accumulation area. If high temperatures continue, the current lower accumulation area will turn into a region with superimposed ice in coming years.

\section{Introduction}

Glaciers and ice caps have dominated the cryospheric component to global average sea level rise during the past century $\left(0.5 \mathrm{~mm} \mathrm{yr}^{-1}\right.$ or about $70 \%$ of the total cryospheric component for the period 1961-2003; Solomon et al., 2007) due to their relatively short response times to climate variability. However, the largest freshwater reservoir in the Northern Hemisphere is the Greenland ice sheet, which would cause 


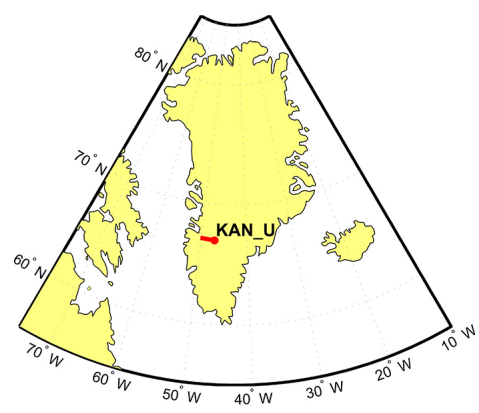

(a)

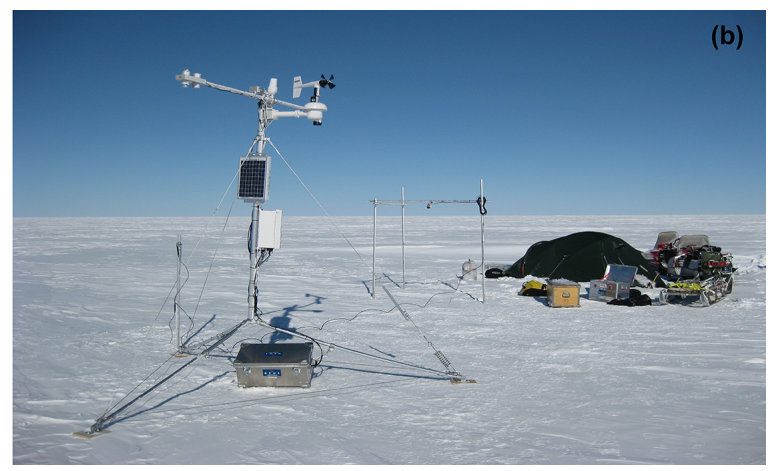

Figure 1. (a) Map of Greenland with the location of KAN_U. (b) Picture taken after the installation of KAN_U (April 2009).

a sea level rise of $7.4 \mathrm{~m}$ if completely melted (Bamber et al., 2013). The average sea level rise contribution from the ice sheet has increased from $0.09 \mathrm{~mm} \mathrm{yr}^{-1}$ over the period 1992-2001 to $0.6 \mathrm{~mm} \mathrm{yr}^{-1}$ over the period 2002-2011, according to the latest IPCC report (Vaughan et al., 2013). The sheer volume of the ice sheet and the relatively large warming of the polar regions may yield an increasingly dominant contribution to cryospheric mass loss in coming decades.

An increasingly important driver of this accelerating mass loss is surface melt and subsequent run-off (Shepherd et al., 2012). Between 2009 and 2012, roughly $84 \%$ of the Greenland ice sheet's increased mass loss was due to enhanced surface run-off and reduced surface mass budget (SMB) (Ettema et al., 2009, 2010; Enderlin et al., 2014). Increased melt is primarily the result of atmospheric warming (Huybrechts and de Wolde, 1999; Huybrechts et al., 2011) and the darkening of the ice sheet (Bøggild et al., 2010; Wientjes and Oerlemans, 2010; Box et al., 2012; Van As et al., 2013). It has been postulated that the sea level rise associated with an increase in meltwater production can be substantially buffered by water refreezing in snow and firn (Harper et al., 2012). However, it has also been suggested that under moderate warming the ice sheet will lose $50 \%$ of its capacity to retain water by the end of the century (Van Angelen et al., 2013), although there is considerable uncertainty involved in retention estimates based on SMB simulations (Vernon et al., 2013).

In situ measurements are essential for understanding the impact of the changing atmospheric conditions on the ice sheet. In the Kangerlussuaq region, West Greenland, seven automatic weather stations (AWSs) and nine SMB stakes constitute a relatively dense network of in situ measurements (Van de Wal et al., 1995; Greuell et al., 2001; Van den Broeke et al., 2008a; Van As et al., 2012). The uppermost AWS, KAN_U, was established on 4 April $2009\left(67^{\circ} 0^{\prime} 0^{\prime \prime} \mathrm{N}\right.$, $47^{\circ} 1^{\prime} 1^{\prime \prime} \mathrm{W}$; Fig. 1). Located approximately $140 \mathrm{~km}$ inland from the ice margin and at about $1840 \mathrm{~m}$ a.s.l. (above sea level), KAN_U is one of the few AWSs in Greenland located in the lower accumulation area, where small changes in climate forcing will likely have the largest impact on ice sheet near-surface stratigraphy.
In the Kangerlussuaq region, approximately $150 \mathrm{~km}$ of mountainous tundra separates the ice sheet from the ocean. Characteristic for the ice sheet in this region is a relatively wide $(\sim 100 \mathrm{~km})$ ablation area. The equilibrium line altitude (ELA), where annual accumulation and ablation are equal, was estimated to be $1535 \mathrm{~m}$ a.s.l. for the period of 1990-2003 (Van de Wal et al., 2005) but is reported to have increased to $1553 \mathrm{~m}$ a.s.l. for the period of 1990-2011 (Van de Wal et al., 2012). At $1520 \mathrm{~m}$ a.s.l., superimposed ice becomes evident at the ice sheet surface at the end of every ablation season, and its up-glacier extent is estimated to reach about $1750 \mathrm{~m}$ a.s.l. (Van den Broeke et al., 2008a). The percolation area is found at higher elevations, up to about $2500 \mathrm{~m}$ a.s.l., which is the lower limit of the dry snow area.

The ablation area in this region has been studied extensively. Van den Broeke et al. (2008a) presented 4 years of radiation measurements below the ELA. The lowest albedo values are found at the intermediate AWS S6 (1020 m a.s.1.) due to a "dark band" induced by surface meltwater (Greuell, 2000; Wientjes and Oerlemans, 2010). Melt modelling revealed not only an increase in summer melt toward the margin, and a decrease in sensible heat flux with increasing elevation, but also an increase in the importance of shortwave radiation in the surface energy balance (SEB) during melt at higher elevations (Van den Broeke et al., 2008b, 2011). An annual cycle in surface roughness length has been found to exist over a large part of the ablation area (Smeets and van den Broeke, 2008). This determines part of the variability in the turbulent heat fluxes during the summer months (Van den Broeke et al., 2009). This latter study showed that the regional katabatic winds, in combination with the variable surface roughness at lower elevations, provides significant year-round turbulent heat transfer in a stable surface layer. An increasing wind speed with surface elevation was identified, contrary to what would be expected from katabatically forced wind over an ice surface flattening with elevation. This is due to the larger surface roughness near the margin (Smeets and van den Broeke, 2008), the increasing influence of the large-scale pressure gradient force (Van Angelen et al., 2011), and the proximity of pooled cold air over 
Table 1. Sensors and their published accuracies.

\begin{tabular}{lll}
\hline Parameter & Sensor & Accuracy \\
\hline Air pressure & Campbell CS100 & $2 \mathrm{hPa}$ at -40 to $60^{\circ} \mathrm{C}$ \\
Aspirated air temperature & Rotronic MP100H aspirated (Pt100) & 0.03 at $0^{\circ} \mathrm{C}$ \\
Relative humidity & Rotronic MP100H aspirated (HygroClip R3) & $1.5 \%$ at $23^{\circ} \mathrm{C}$ \\
Shortwave radiation (incoming and reflected) & Kipp \& Zonen CNR4 (Pyranometer) & $10 \%$ for daily totals \\
Longwave radiation (incoming and emitted) & Kipp \& Zonen CNR4 (Pyrgeometer) & $10 \%$ for daily totals \\
Wind speed and direction & Young 05103-5 & $0.3 \mathrm{~m} \mathrm{~s}^{-1} ; 3^{\circ}$ \\
Surface height & Campbell SR50A & $10^{-2} \mathrm{~m} \mathrm{or} 0.4 \%$ \\
\hline
\end{tabular}

the tundra that sets up an opposing pressure gradient force in the boundary layer during winter. Van As et al. (2012) quantified the extreme surface melt in the Kangerlussuaq region in 2010, validated by river discharge measurements.

At elevations above the superimposed ice area and below the dry snow area (i.e. $\sim 1750-2500 \mathrm{~m}$ a.s.1.), sufficient melt occurs to impact snow/firn properties but not enough to reveal bare ice. In a warming climate with melt occurring at higher elevations, this area would comprise an increasingly large surface area of the ice sheet due to the ice sheet's flattening with increasing elevation (McGrath et al., 2013). A rare event in July 2012 caused melt at all elevations of the ice sheet (Nghiem et al., 2012). Bennartz et al. (2013) partially attributed this Greenland-wide event of increased nearsurface temperatures to thin, low-level liquid clouds. These clouds, while optically thick and low enough to enhance downward longwave radiation, were thin enough for solar radiation to reach the ice sheet surface. They were present at Summit, the highest location on the ice sheet ( $3216 \mathrm{~m}$ a.s.1.), about $30 \%$ of the time during the 2012 summer months.

A large difference between the ablation and accumulation areas is that in the accumulation area, processes within the snow/firn layers, such as meltwater percolation and refreezing, significantly impact the mass budget (e.g. Harper et al., 2012). The melt-albedo feedback (Box et al., 2012) is also an important process in the accumulation area, since, once activated, it can result in abnormally high ablation.

Our aim is to assess the sensitivity of SMB to atmospheric forcing in the lower accumulation area by using AWS measurements as input for a SEB model. The 5-year period of AWS measurements (2009-2013) spans a wide range of melting conditions, including the record melt years of 2010 and 2012 (Tedesco et al., 2011, 2013; Van As et al., 2012; Nghiem et al., 2012; Hanna et al., 2014) and years with moderate melting such as 2009 and 2013. We add temporal perspective by discussing Kangerlussuaq air temperatures since 1976 and Moderate Resolution Imaging Spectroradiometer (MODIS) albedo values since 2000. Below, we first describe the observations and SEB calculations, after which we present atmospheric conditions and surface energy fluxes at KAN_U and the changes therein due to recent years with extreme melt. Finally, we investigate the importance of the melt-albedo feedback on the SMB of the lower accumulation area and discuss how changes in the firn can yield SMB variability on an interannual timescale.

\section{Methods}

\subsection{AWS measurements}

KAN_U is part of the $\sim 20$ AWSs comprising the Programme for Monitoring of the Greenland Ice Sheet (PROMICE) network (Ahlstrøm et al., 2008). Measurements include ambient air pressure, relative humidity and aspirated temperature $\left(T_{\mathrm{a}}\right)$ at $2.7 \mathrm{~m}$ height above the ice sheet surface, wind speed, and direction at $3.1 \mathrm{~m}$ height, as well as incoming and reflected solar/shortwave $\left(E_{\mathrm{S}}^{\downarrow}, E_{\mathrm{S}}^{\uparrow}\right)$ and downward and emitted terrestrial/longwave $\left(E_{\mathrm{L}}^{\downarrow}, E_{\mathrm{L}}^{\uparrow}\right)$ radiation components at 10-minute intervals. Accumulation and ablation are measured by two sonic rangers, one attached to the AWS and one on a separate stake assembly (Fig. 1b). Sensor specifications are listed in Table 1 . The AWS transmits hourly measurements during the summer period and daily during winter (Citterio et al., 2015).

AWSs installed on glaciers are prone to tilt due to transient evolution of the ice or firn surface. The importance of accounting for pyranometer tilt has been discussed by MacWhorter and Weller (1991). AWSs located in accumulation areas are comparatively stable due to the accumulated snow on the base of the tripod. The maximum tilt registered by KAN_U was $3.0^{\circ}$. A tilt correction for the solar radiation measurements is made after Van As (2011).

Two gaps in (sub-)hourly measurements exist due to a malfunctioning memory card, from 27 October 2010 until 22 April 2011 and from 26 October 2011 until 21 January 2012. During these periods, when only transmitted daily values are available, measurements from a second AWS, S10 erected on 17 August 2010 at $\sim 50 \mathrm{~m}$ distance from KAN_U, were used and adjusted by linear regression to eliminate systematic offsets due to different measurement heights. The overlapping records of the two time series revealed high cross-correlations and low root-mean-squared deviations (RMSD) for every measured parameter (Table 2). Due to technical issues with $\mathrm{S} 10, E_{\mathrm{L}}^{\downarrow}, E_{\mathrm{L}}^{\uparrow}$, and $T_{\mathrm{a}}$ measure- 
Table 2. Linear regression parameters for hourly values of KAN_U and S10 AWSs: slope $(\chi)$, intercept $(\psi)$, correlation coefficients $(R)$, and root-mean-squared deviations (RMSD).

\begin{tabular}{lcrcl}
\hline S10-KAN_U & $\chi$ & $\psi$ & $R$ & RMSD \\
\hline$E_{\mathrm{S}}^{\downarrow *}$ & 1.010 & - & 0.99 & $37.25\left(\mathrm{~W} \mathrm{~m}^{-2}\right)$ \\
$E_{\mathrm{S}}^{\uparrow *}$ & 0.987 & - & 0.99 & $24.71\left(\mathrm{~W} \mathrm{~m}^{-2}\right)$ \\
$E_{\mathrm{L}}^{\downarrow}$ & 1.003 & -6.06 & 0.99 & $8.92\left(\mathrm{~W} \mathrm{~m}^{-2}\right)$ \\
$E_{\mathrm{L}}^{\uparrow}$ & 0.990 & -0.25 & 1.00 & $3.62\left(\mathrm{~W} \mathrm{~m}^{-2}\right)$ \\
$T_{\mathrm{a}}$ & 0.995 & -0.25 & 1.00 & $0.50\left({ }^{\circ} \mathrm{C}\right)$ \\
Ambient air pressure & 0.990 & 7.77 & 1.00 & $0.45(\mathrm{hPa})$ \\
Relative humidity & 0.899 & 10.31 & 0.91 & $3.78(\%)$ \\
Wind speed* & 0.928 & - & 0.99 & $0.66(\mathrm{~m} \mathrm{~s}-1)$ \\
$\alpha_{2010}^{* *}$ & - & - & 0.93 & $0.032(-)$ \\
$\alpha_{2011}^{* *}$ & - & - & 0.94 & $0.028(-)$ \\
$\alpha_{2012}^{* *}$ & - & - & 0.91 & $0.066(-)$ \\
* Regression line forced through 0; ${ }^{* *} 24 \mathrm{~h}$ running averages for the months May until \\
September.
\end{tabular}

ment gaps from 9 February 2011 until 30 April 2012 were filled with a similar approach, using measurements from the AWS S9 located $53 \mathrm{~km}$ closer to the ice sheet margin. Any added uncertainty from using adjusted wintertime measurements will have minimal impact on the summertime results presented below.

The broadband albedo is the fraction of the incoming shortwave radiation reflected at the ice sheet surface and an important parameter in studying the changes in the accumulation area:

$\alpha=\left|\frac{E_{\mathrm{S}}^{\uparrow}}{E_{\mathrm{S}}^{\downarrow}}\right|$.

To verify its accuracy, albedo was compared for both AWSs KAN_U and S10 for the warm seasons (May-September) of 2010, 2011, and 2012 (Table 2). For hourly values, the RMSD for 2010 and 2011 was only $\sim 0.03$. The RMSD for 2012 was 0.07 due to the higher spatial variability in surface reflectance after substantial melt.

\subsection{Surface radiation budget}

The radiation budget at the ice sheet surface is given by the sum of solar and terrestrial radiation components:

$E_{\mathrm{R}}=E_{\mathrm{S}}^{\downarrow}+E_{\mathrm{S}}^{\uparrow}+E_{\mathrm{L}}^{\downarrow}+E_{\mathrm{L}}^{\uparrow}=E_{\mathrm{S}}^{\mathrm{Net}}+E_{\mathrm{L}}^{\mathrm{Net}}$.

Fluxes are here taken as positive when directed toward the ice sheet surface. By the inclusion of albedo and utilizing the Stefan-Boltzmann law, this can be rewritten as

$E_{\mathrm{R}}=(1-\alpha) E_{\mathrm{S}}^{\downarrow}+\varepsilon E_{\mathrm{L}}^{\downarrow}-\varepsilon \sigma T_{\mathrm{S}}^{4}$,

with $\sigma$ being the Stefan-Boltzmann constant $\left(5.67 \times 10^{-8}\right.$ $\mathrm{W} \mathrm{m}^{-2} \mathrm{~K}^{-4}$ ) and $T_{\mathrm{S}}$ the surface temperature. The longwave emissivity $\varepsilon$ for snow/firn is assumed equal to 1 (black-body assumption).

\subsection{SEB model}

Various studies have applied SEB models in glaciated areas under different climatic conditions, such as the high Antarctic plateau (Van As et al., 2005) and the Greenland ablation area (Van den Broeke et al., 2008b, 2011). The energy balance at the atmosphere-surface interface is

$E_{\mathrm{M}}=E_{\mathrm{R}}+E_{\mathrm{H}}+E_{\mathrm{E}}+E_{\mathrm{G}}+E_{\mathrm{P}}$,

where $E_{\mathrm{H}}, E_{\mathrm{E}}, E_{\mathrm{G}}$, and $E_{\mathrm{P}}$ are the turbulent sensible, turbulent latent, subsurface conductive, and rain-induced energy fluxes respectively.

Rainfall is assumed to be at melting-point temperature $\left(T_{0}=273.15 \mathrm{~K}\right)$, and thus $E_{\mathrm{P}}$ is non-zero when $T_{\mathrm{S}}$ is below freezing:

$E_{\mathrm{P}}=\rho_{\mathrm{w}} c_{\mathrm{w}} \dot{r}\left(T_{0}-T_{\mathrm{s}}\right)$,

where $c_{\mathrm{W}}$ is the specific heat of water $\left(4.21 \mathrm{~kJ} \mathrm{~kg}^{-1} \mathrm{~K}^{-1}\right.$ at $0^{\circ} \mathrm{C}$ and $999.84 \mathrm{~kg} \mathrm{~m}^{-3}$ ) and $\dot{r}$ is the rainfall rate. The rainfall rate is assumed to be non-zero under conditions of heavy cloud cover during periods with non-freezing air temperatures (see below).

The energy balance is solved for the one unknown variable $T_{\mathrm{s}}$, which is limited to the melting-point temperature $(273.15 \mathrm{~K})$, and the imbalance in Eq. (4) is attributed to melt $\left(E_{\mathrm{M}}\right)$. For sub-freezing $T_{\mathrm{S}}$ values all other SEB components are in balance and surface melt does not occur. $E_{\mathrm{H}}$ and $E_{\mathrm{E}}$ are calculated using the "bulk method" as described by Van As et al. (2005). This method uses atmospheric stability and thus depends on $T_{\mathrm{S}}$, implying that Eq. (4) has to be solved iteratively.

The average surface roughness length for momentum $z_{0}$ at this elevation would realistically be $\sim 10^{-4} \mathrm{~m}$ (Smeets and van den Broeke, 2008). During summer, the ice sheet surface melts occasionally, and thus smoothes while attaining a smaller $z_{0}\left(\sim 10^{-5} \mathrm{~m}\right)$. Slightly increased roughness is expected during wintertime due to sastrugi, while drifting snow (Lenaerts et al., 2014) can increase $z_{0}$ in cases up to $10^{-3} \mathrm{~m}$. In the present study, $z_{0}$ is kept constant at $10^{-4} \mathrm{~m}$. A series of test runs showed that the results of this study were not very sensitive to the range of plausible $z_{0}$ values. The scalar roughness lengths for heat and moisture are calculated according to Andreas (1987).

Subsurface heat transfer is calculated with $0.1 \mathrm{~m}$ spatial resolution (20 m depth; 200 layers) and is forced by temperature changes at the surface and latent heat release when water refreezes within the firn. Heat conduction is calculated using effective conductivity as a function of firn density (Sturm et al., 1997) and specific heat of firn as a function of temperature (Yen, 1981). The calculations are initialized using thermistor string temperatures from April 2009 and depth-adjusted firn core densities measured on 2 May 2012. The subsurface part of the model includes a percolation/refreezing scheme based on Illangasekare et 

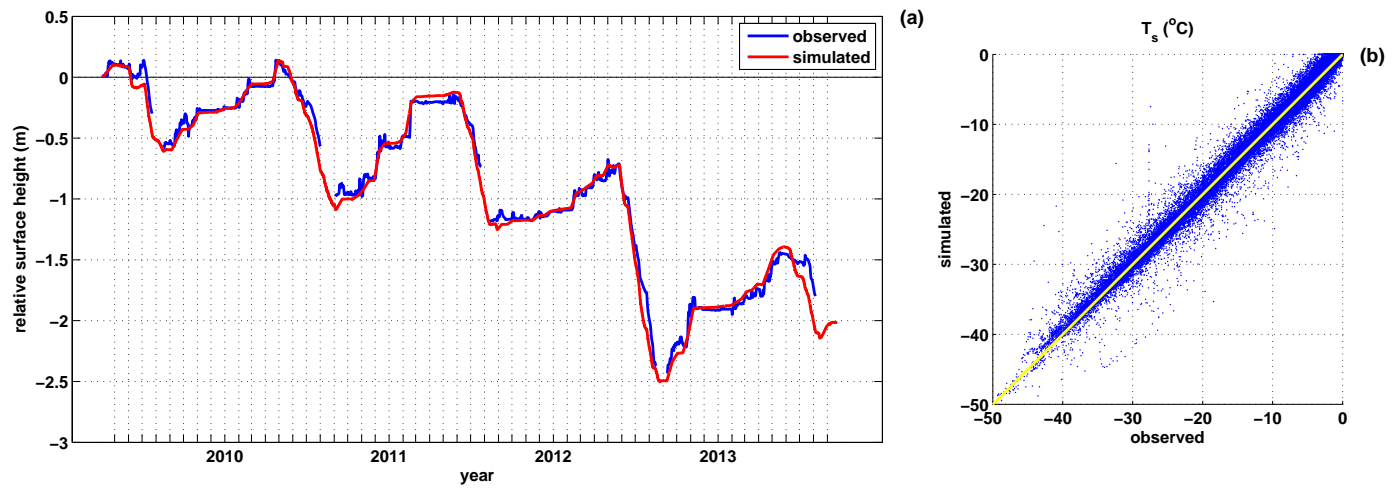

Figure 2. SEB model validation: (a) observed and simulated relative surface height for the period of observations. (b) Simulated against observed $T_{\mathrm{S}}\left(R^{2}=0.98 ;\left(\Delta T_{\mathrm{S}}\right) \mathrm{avg}=0.11^{\circ} \mathrm{C} ; \mathrm{RMSE}=1.43^{\circ} \mathrm{C}\right)$.

al. (1990), assuming active percolation within snow/firn. Provided that there is production of meltwater at the surface, the amount of refreezing is limited either by the available pore volume or by the available cold content at each level. The scheme simulates water transport and subsequent refreezing as the progression of a uniform warming front into the snow/firn and is active for all melt seasons except for 2012. In 2012, surface run-off dominated water movement after 14 July, as clearly visible on Landsat imagery (not shown). This coincided with the surfacing of a $6 \mathrm{~m}$ thick ice layer in the model, which was also found in firn cores (Machguth et al., 2015). Consistent with these observations, we use $6 \mathrm{~m}$ of ice (density of $900 \mathrm{~kg} \mathrm{~m}^{-3}$ ) as a threshold that causes meltwater to run off horizontally, shutting down vertical percolation.

Solid precipitation is added in the model based on KAN_U sonic ranger measurements, assuming a rounded average snow density of $400 \mathrm{~kg} \mathrm{~m}^{-3}$ observed in snow-pit measurements. Although rain occurs infrequently at $1840 \mathrm{~m}$ a.s.l., a rain estimate is incorporated with prescribed precipitation rates for each year during hours with thick cloud cover producing $E_{\mathrm{L}}^{\downarrow}$ values that exceed black-body radiation using the air temperature $\left(E_{\mathrm{L}}^{\downarrow}>\sigma T_{\mathrm{a}}^{4}\right)$ and $T_{\mathrm{a}}$ is above freezing. Evaluating this against winter accumulation, the following precipitation rates were derived and prescribed to the rain calculation: $2.0 \mathrm{~mm} \mathrm{~h}^{-1}$ for 2009-2010 and 2012-2013, 3.5 $\mathrm{mm} \mathrm{h}^{-1}$ for 2010-2011, and $0.5 \mathrm{~mm} \mathrm{~h}^{-1}$ for 2011-2012. Using this approach, the model produces liquid precipitation during the summer months only; by the end of the 5-year period it amounts to a total of $0.26 \mathrm{~m}$ w.e. (water equivalent), $15 \%$ of the total precipitation over the 5 years. The contribution of rain in the energy balance is minor; the total energy added to the surface for the whole study period is approximately $1.15 \mathrm{MJ} \mathrm{m}^{-2}$, which could yield a total of $9 \mathrm{~mm}$ of melted snow.

The performance of the model in terms of ablation is illustrated by comparing simulated surface changes with the measured surface height changes due to ablation and accu- mulation (Fig. 2a). The model accurately reproduces the melt rates during every melt season, yet this validation does not cover the whole melt season. We found that the AWS tripod and stake assembly are prone to sinking somewhat into warm, melting firn during the second part of the melt season (note the measurement gaps). In a second model validation exercise, we compare simulated and measured $T_{\mathrm{S}}$ (inferred from the $E_{\mathrm{L}}^{\uparrow}$ ) in Fig. $2 \mathrm{~b}$ and find they correlate well $\left(R^{2}=0.98\right)$ with an average difference of $0.11^{\circ} \mathrm{C}$ and rootmean-squared error (RMSE) of $1.43^{\circ} \mathrm{C}$. Part of this difference can be attributed to the seemingly overestimated $10 \%$ $E_{\mathrm{L}}^{\uparrow}$ measurement uncertainty as reported by the sensor manufacturer, which would yield a RMSE of $6.2^{\circ} \mathrm{C}$ of $T_{\mathrm{S}}$ values.

\subsection{Additional measurements}

For a study with a 5-year time span, it is useful to provide a longer temporal perspective. For this, we use the air temperature record from Kangerlussuaq airport observed by the Danish Meteorological Institute (DMI) since 1973 in support of aircraft operations (Cappelen, 2013). Full observational suite coverage is available since 1976 . Monthly $T_{\mathrm{a}}$ from the airport correlates well with the KAN_U time series $(R=0.97)$, indicating that Kangerlussuaq measurements can be used for providing temporal perspective, despite the $160 \mathrm{~km}$ distance that separates the two measurement sites. Finally, we use the pixel nearest to KAN_U in 5-by-5 km re-gridded MODIS albedo product (MOD10A1) to investigate albedo variability over the 2000-2013 period.

\section{Results}

\subsection{Meteorological observations}

The importance of katabatic and synoptic forcing on nearsurface wind direction are roughly equivalent at the elevation of KAN_U (Van Angelen et al., 2011). The average wind direction is south-southeast $\left(\sim 150^{\circ}\right.$; Fig. 3a). However, in a 
Table 3. Annual and summer (June-July-August) average meteorological parameters at KAN_U.

\begin{tabular}{|c|c|c|c|c|c|}
\hline KAN_U & $2009 *$ & 2010 & 2011 & 2012 & $2013^{* *}$ \\
\hline \multicolumn{6}{|c|}{ Annual averages } \\
\hline$T_{\mathrm{a}}\left({ }^{\circ} \mathrm{C}\right)$ & -15.5 & -11.6 & -18.0 & -14.3 & -15.4 \\
\hline Ambient air pressure $(\mathrm{hPa})$ & 799 & 804 & 797 & 800 & 799 \\
\hline Specific humidity $\left(\mathrm{g} \mathrm{kg}^{-1}\right)$ & 1.5 & 2.0 & 1.4 & 1.9 & 1.5 \\
\hline Wind speed $\left(\mathrm{m} \mathrm{s}^{-1}\right)$ & 7.0 & 7.0 & 6.2 & 6.5 & 7.0 \\
\hline Albedo & 0.85 & 0.82 & 0.82 & 0.79 & 0.80 \\
\hline \multicolumn{6}{|c|}{ Summer (JJA) averages } \\
\hline$T_{\mathrm{a}}\left({ }^{\circ} \mathrm{C}\right)$ & -4.3 & -1.8 & -2.9 & -1.8 & -4.5 \\
\hline Ambient air pressure $(\mathrm{hPa})$ & 809 & 808 & 811 & 811 & 804 \\
\hline Specific humidity $\left(\mathrm{g} \mathrm{kg}^{-1}\right)$ & 2.9 & 3.6 & 3.3 & 3.7 & 2.8 \\
\hline Wind speed $\left(\mathrm{m} \mathrm{s}^{-1}\right)$ & 5.3 & 5.2 & 5.0 & 4.6 & 5.2 \\
\hline Albedo & 0.78 & 0.77 & 0.78 & 0.71 & 0.78 \\
\hline
\end{tabular}

* Average 2010-2013 for January, February, and March; ** average 2009-2012 for October, November, and December.
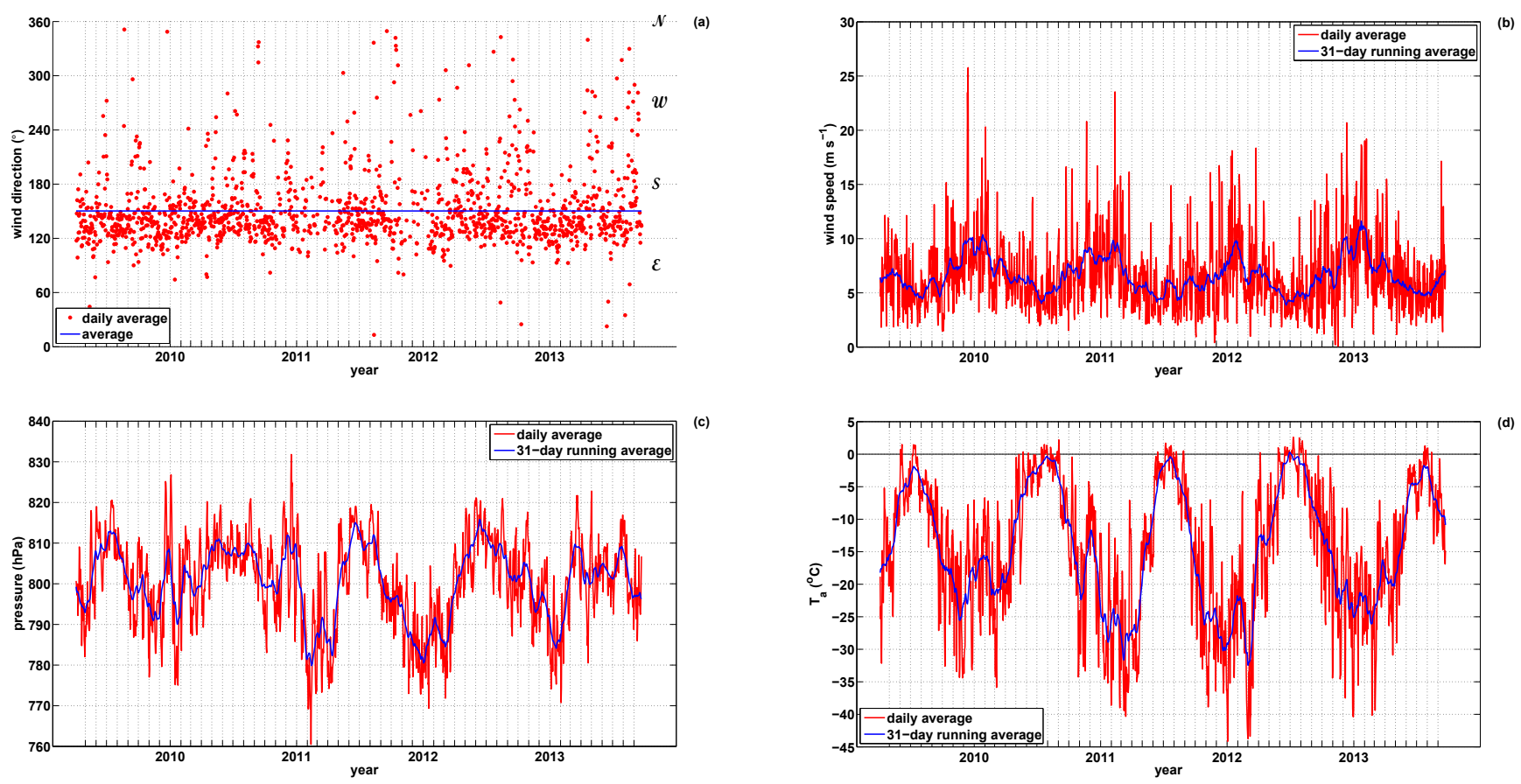

Figure 3. Average values of (a) wind direction, (b) wind speed, (c) air pressure, and (d) air temperature at KAN_U.

case study of the 2012/2013 winter (Van As et al., 2014), the prevailing wind direction was $\sim 135^{\circ}$ (southeast), suggesting an influential katabatic regime in which air drains downslope and is deflected by the Coriolis effect. Wind speed is higher during winter (Fig. 3b); annual average values are 6$7 \mathrm{~m} \mathrm{~s}^{-1}$, whereas summer (June-July-August) average values are around $5 \mathrm{~m} \mathrm{~s}^{-1}$ (Table 3 ). Winds exceeding $15 \mathrm{~m} \mathrm{~s}^{-1}$ occur primarily during the winter period and rarely exceed $20 \mathrm{~m} \mathrm{~s}^{-1}$ when averaged over $24 \mathrm{~h}$. The barometric pressure of about $800 \mathrm{hPa}$ exhibits an annual cycle with relatively high pressure in summer (Fig. 3c), favouring more stable, clearsky conditions. The specific humidity also varies annually; it peaks in summer with annual average about $1.7 \mathrm{~g} \mathrm{~kg}^{-1}$.

The year 2010 was the warmest year of the record (Table 3), with the winter (December-January-February) of 2009-2010 being $4.0^{\circ} \mathrm{C}$ warmer than the 2009-2013 average and the summer only being equaled by $2012\left(-1.8^{\circ} \mathrm{C}\right.$; Table 3). May 2010 was especially warm, at -6.2 or $5.1^{\circ} \mathrm{C}$ above the 2009-2013 average. Positive $T_{\mathrm{a}}$ persisted during the end of the melt season resulting in a $-1.1^{\circ} \mathrm{C}$ monthly 
Table 4. Surface height changes and mass budgets (measured in winter and calculated in summer) at KAN_U in metres and m w.e. respectively and ablation duration. The uncertainty associated with surface height change is estimated to be $0.2 \mathrm{~m}$. The mass budgets are calculated with an assumed snow density of $360 \mathrm{~kg} \mathrm{~m}^{-3}$ (the average density of the uppermost $0.9 \mathrm{~m}$ measured on 26 April 2013), with uncertainty estimated at $40 \mathrm{~kg} \mathrm{~m}^{-3}$ (standard deviation among the snow-pit measurements). The snow density assumption was not needed in 2012 and 2013, when actual density measurements were conducted.

\begin{tabular}{lllllll}
\hline & $\begin{array}{c}\text { Winter } \\
\text { height } \\
\text { change }\end{array}$ & Winter budget & $\begin{array}{c}\text { Summer } \\
\text { height } \\
\text { change }\end{array}$ & $\begin{array}{c}\text { Summer } \\
\text { budget }\end{array}$ & $\begin{array}{l}\text { Net } \\
\text { budget }\end{array}$ & Ablation period \\
\hline $2008-2009$ & $+1.6^{*}$ & $+0.59^{*} \pm 0.15$ & -0.7 & $-0.26 \pm 0.08$ & $+0.34^{*} \pm 0.12$ & 1 Jun-19 Aug \\
$2009-2010$ & +0.7 & $+0.25 \pm 0.08$ & -1.2 & $-0.44 \pm 0.09$ & $-0.19 \pm 0.12$ & 30 Apr-5 Sep \\
$2010-2011$ & +1.0 & $+0.37 \pm 0.08$ & -1.1 & $-0.41 \pm 0.09$ & $-0.04 \pm 0.12$ & 28 May-13 Aug \\
$2011-2012^{* *}$ & +0.7 & $+0.25 \pm 0.08$ & -1.8 & $-0.86 \pm 0.14$ & $-0.61 \pm 0.16$ & 27 May-24 Aug \\
$2012-2013^{* * *}$ & +1.2 & $+0.45 \pm 0.09$ & -0.8 & $-0.27 \pm 0.08$ & $+0.18 \pm 0.12$ & 29 May-17 Aug \\
\hline
\end{tabular}

* Value inferred from Van de Wal et al. (2012); ${ }^{* *}$ estimate based on snow-pit densities from May 2012; ${ }^{* * *}$ estimate based on snow-pit densities from May 2013.

average for August. The high 2010 temperatures influenced surface ablation by inducing the early onset of melt. In 2010 , ablation at KAN_U occurred from late April until early September, whereas, for instance, the 2009 melt season at KAN_U spanned early June until mid-August.

The average SMB over the period 1994-2010 at KAN_U is $+0.27 \mathrm{~m}$ w.e. (Van de Wal et al., 2012). Melt at this elevation occurs during each melt season. The winter 2009/2010 accumulation of $0.25 \mathrm{~m}$ w.e. was relatively low, amounting to just $65 \%$ of the 2009-2013 average (Table 4). During the 2010 melt season, all the snow that had accumulated since the end of the previous melt season ablated, including part of the underlying firn, resulting in the first negative SMB year on record (Table 4). The stake measurements from Van de Wal et al. (2012) document a 2-year surface height change of $+0.42 \mathrm{~m}$ on average for 2008-2010 at the same location (S10), corresponding to $+0.15 \mathrm{~m}$ w.e. assuming a snowpit density of $360 \mathrm{~kg} \mathrm{~m}^{-3}$. From this estimate, we infer the winter and net SMB for 2009 to be +0.59 and $+0.34 \mathrm{~m}$ w.e. respectively.

During winter 2011/2012, accumulation was similar to that in winter $2009 / 2010$. In spring 2012 , positive $T_{\mathrm{a}}$ was first recorded during April (at $-12.8^{\circ} \mathrm{C}$ April 2012 was the warmest April on record), followed by a relatively warm May $\left(-8.6^{\circ} \mathrm{C}\right)$. Ablation rates were already high in late May 2012 (7.2 mm w.e. day ${ }^{-1}$; Charalampidis and van As, 2015). June and July were the warmest of the 5-year record with -1.5 and $-0.6^{\circ} \mathrm{C}$ monthly average $T_{\mathrm{a}}$ respectively. With the summer of 2012 on average as warm as that of 2010 , but the ablation period shorter by 39 days (Table 4), the summer SMB was -0.86 m w.e., making 2012 the most strongly negative SMB year $(-0.61 \mathrm{~m}$ w.e.) to be recorded at this location (Van de Wal et al., 2005, 2012).

\subsection{Surface energy fluxes}

Solar radiation exhibits a strong annual cycle at this location above the Arctic Circle (Fig. 4a). In the absence of topographic shading or a significant surface slope $\left(<1^{\circ}\right)$ the day-to-day variability in incoming shortwave radiation at this elevation is dominated by cloudiness and the solar zenith angle. The highest daily $E_{S}^{\downarrow}$ values occur in June and exceed $400 \mathrm{~W} \mathrm{~m}^{-2}$, while at the ELA they are just below $400 \mathrm{~W} \mathrm{~m}^{-2}$ (Van den Broeke et al., 2008a) due to more frequent cloud cover and a thicker overlying atmosphere. Whereas $E_{\mathrm{S}}^{\downarrow}$ increases with elevation from the ELA to KAN_U, $E_{\mathrm{S}}^{\mathrm{Net}}$ obtains daily values of up to $100 \mathrm{~W} \mathrm{~m}^{-2}$ both at the ELA and at KAN_U, implying that solar energy input is regulated by surface reflectance.

Terrestrial radiation exhibits an annual cycle of smaller amplitude (Fig. 4a). The annual variations of the downward and emitted longwave radiation are governed by the temperature and emissivity variations of the atmosphere and the ice sheet surface respectively. Hence, the absolute magnitudes of both components are larger during the summer period. $E_{\mathrm{L}}^{\downarrow}$ fluctuations depend primarily on cloud cover. $E_{\mathrm{L}}^{\uparrow}$ is a sink to the SEB and during summer is limited by the melting surface with the maximum energy loss being $316 \mathrm{~W} \mathrm{~m}^{-2}$. This results in predominantly negative $E_{\mathrm{L}}^{\mathrm{Net}}$ values throughout the year. The energy loss peaks during June and July.

The $E_{\mathrm{R}}$ annual cycle displays an energy gain at the ice sheet surface during May to August and energy loss the rest of the year (Fig. 4b). This winter energy loss is primarily compensated by downward sensible heat flux. Calculated $E_{\mathrm{H}}$ is typically positive throughout the year, with highest values in winter when $E_{\mathrm{R}}$ is most negative, heating the ice sheet surface while cooling the atmospheric boundary layer (Fig. 4b). This facilitates the katabatic forcing and thus enhances wind speed and further turbulent energy exchange between the atmosphere and the ice sheet surface. The contribution of $E_{\mathrm{H}}$ 


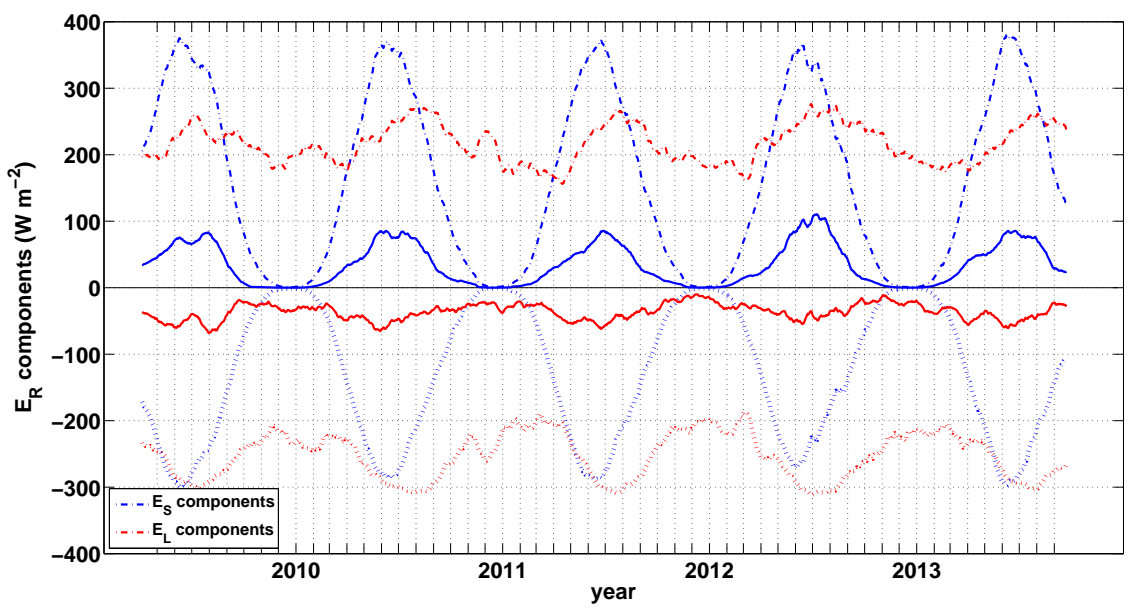

(a)

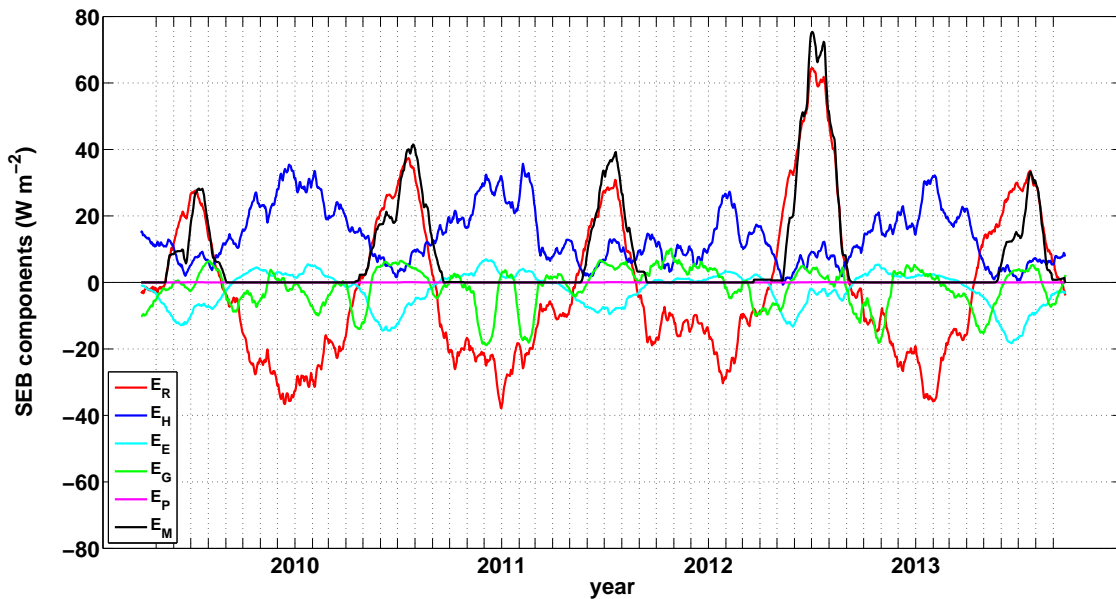

(b)

Figure 4. (a) Running average values for 31 days of all radiation budget components at KAN_U. Solid lines indicate the net solar and terrestrial radiation components. (b) Same as (a) but for all surface energy balance components.

to melt is smaller than at lower elevations (Van den Broeke et al., 2011). The dominant melt energy source at KAN_U is therefore $E_{\mathrm{R}}$.

$E_{\mathrm{E}}$ changes sign from winter to summer and is on average a small contributor to the annual SEB. During the summer period, $E_{\mathrm{E}}$ is comparable to $E_{\mathrm{H}}$ but with opposite sign, enabling surface cooling by sublimation and/or evaporation (Henneken et al., 1994). In winter, $E_{\mathrm{E}}$ is directed mostly toward the cold ice sheet surface, resulting in heating from deposition.

The annually averaged $E_{\mathrm{G}}$ is mostly negative and of the same magnitude as $E_{\mathrm{E}}\left(3-4 \mathrm{~W} \mathrm{~m}^{-2}\right)$ but with no distinct annual cycle. Melt seasons with substantial refreezing exhibit increased positive summer-averaged $E_{\mathrm{G}}$ since the nearsurface firn temperature is on average higher than $T_{\mathrm{s}}$, leading to conductive heat transport toward the ice sheet surface. Low $E_{\mathrm{G}}$ values in summer indicate limited refreezing in the firn just below the ice sheet surface.

$E_{\mathrm{P}}$ is non-zero but still negligible in summer, when positive air temperatures occur and thus precipitation is liquid.

\subsection{Interannual variability of the SEB and implications for melt}

With the exception of August 2009, when predominantly clear skies caused $E_{\mathrm{S}}^{\downarrow}$ to be $40 \mathrm{~W} \mathrm{~m}^{-2}$ larger and $E_{\mathrm{L}}^{\downarrow}$ $36 \mathrm{~W} \mathrm{~m}^{-2}$ smaller than in the other years, monthly average values of $E_{\mathrm{S}}^{\downarrow}$ at this site are fairly invariant (difference $<25 \mathrm{~W} \mathrm{~m}^{-2}$; Fig. 5a). Often $E_{\mathrm{R}}$ increases when clouds are present over an ice sheet; this is the so-called radiation paradox (Ambach, 1974), as it was observed in April 2012.

Figure $5 \mathrm{~b}$ illustrates the annual cycle of monthly averaged albedo, excluding the winter months. From October to February shortwave radiation values are too low for accurate albedo estimation. Nevertheless, the albedo is expected to be characteristic of fresh dry snow values (0.8-0.9) during winter. High albedo persists until May due to fresh snow deposited on the ice sheet surface. An exception occurred during March and April 2013, when the monthly albedo of 0.78 suggests reduced precipitation input for a prolonged period and the presence of ageing dry snow on the ice sheet sur- 

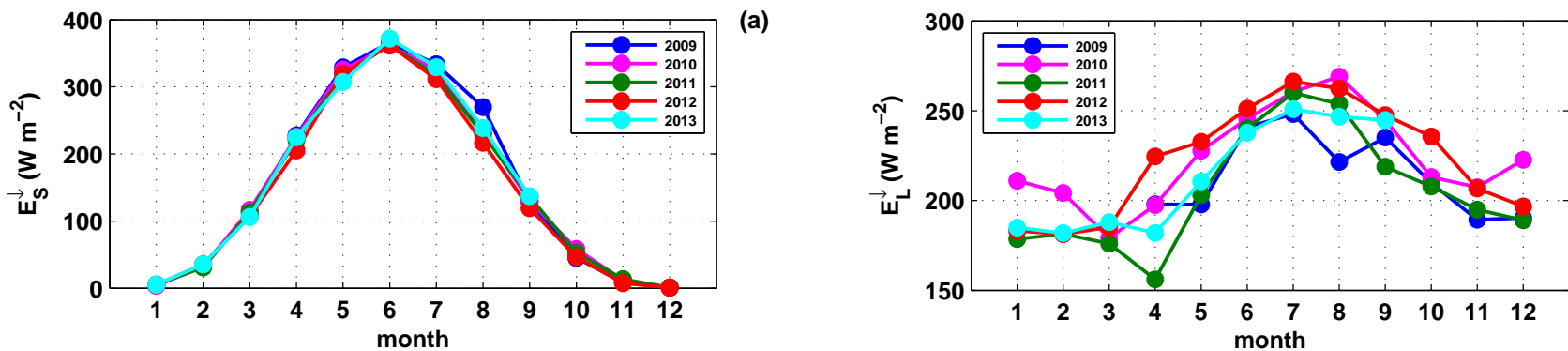

(a)
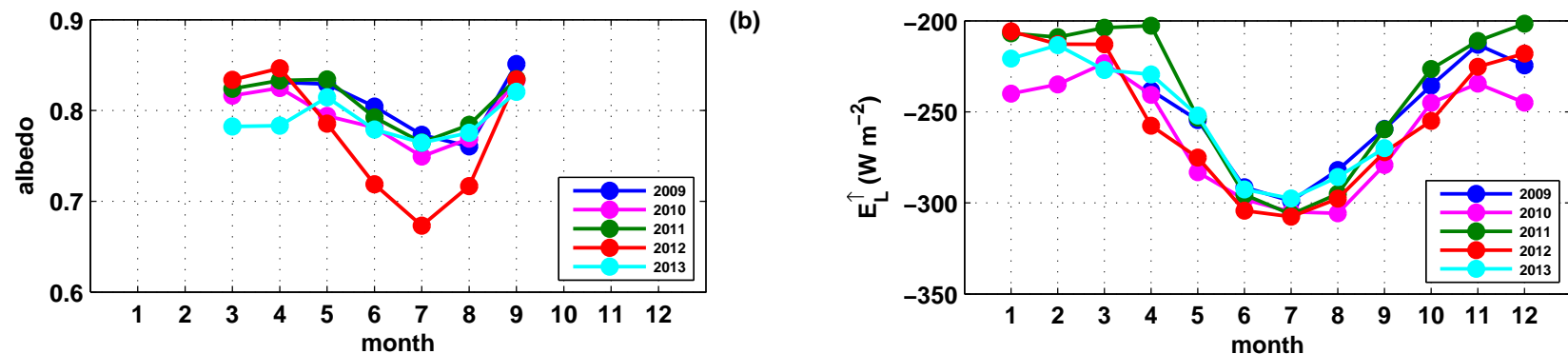

(b)
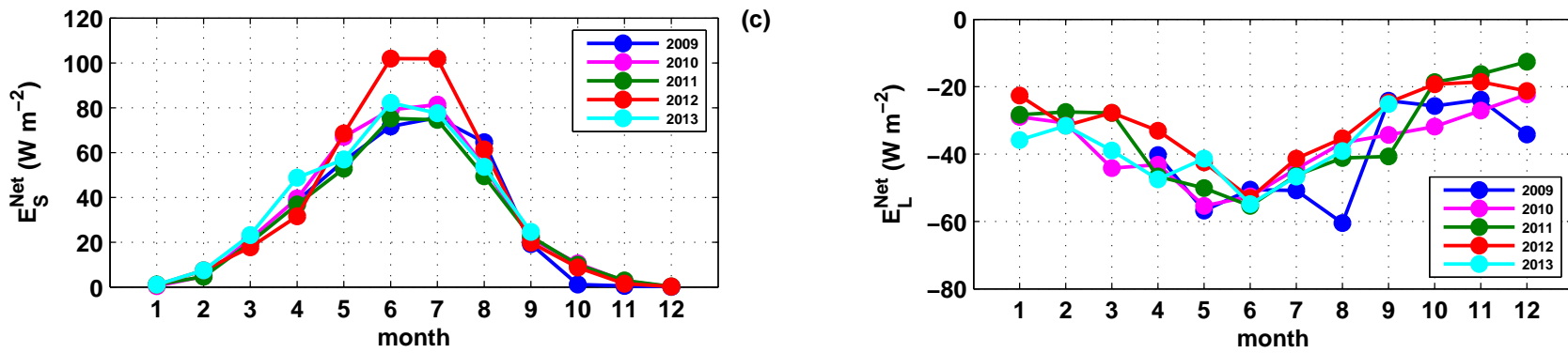

Figure 5. Seasonal cycles for the years 2009-2013 based on monthly averages of (a) incoming shortwave energy flux, (b) surface albedo, and (c) net shortwave energy flux.

face (Cuffey and Paterson, 2010). In the years 2009-2011 and 2013 the albedo gradually decreased beginning late May and during the summer due to the effects of relatively high temperatures and melt on snow metamorphism. During summer, albedo still exceeded 0.75. Although melt at KAN_U still occurs intermittently during August, such melt does not counteract the effect of snowfall events that increase the surface albedo.

The anomalously warm period in June and July 2012 (Fig. 3d) coincided with a larger decrease in surface albedo than in the other years. The combination of enhanced melting, heat-induced snow metamorphosis, and firn saturation reduced the albedo from 0.85 in April to 0.67 in July, reaching a value that is characteristic of soaked snow facies close to the lower elevation snow/firn line (Cuffey and Paterson, $2010)$. As a consequence, $E_{\mathrm{S}}^{\mathrm{Net}}$ increased by approximately $25 \mathrm{~W} \mathrm{~m}^{-2}$ in June and July (32\%; Fig. 5c). This darkening thus functioned as an amplifier of melt (Box et al., 2012; Van

As et al., 2013) and contributed to the large observed ablation (Table 4).

The largest longwave radiation surface emissions occurred during August 2010 and June-July 2012, approaching the theoretical limit of $-316 \mathrm{~W} \mathrm{~m}^{-2}$ for a continuously melting ice sheet surface (Fig. 6b). The concurrent high $E_{\mathrm{L}}^{\downarrow}$ (Fig. 6a; Table 5) was related to high atmospheric temperatures. This caused summer $E_{\mathrm{L}}^{\text {Net }}$ in 2010 and 2012 to exceed its value in other years (Table 5; Van As et al., 2012). While summer $E_{\mathrm{S}}^{\mathrm{Net}}$ was similar in 2009 and 2010 , summer $E_{\mathrm{R}}$ was $69 \%$ larger in 2010 than in 2009, primarily due to the high atmospheric temperatures. During 2012, summer $E_{\mathrm{L}}^{\mathrm{Net}}$ was similar as in 2010. The large summer $E_{\mathrm{S}}^{\text {Net }}$ resulted in summer $E_{\mathrm{R}} 67 \%$ higher than in 2010 (Table 5). The highest daily $E_{\mathrm{R}}$ attained $100 \mathrm{~W} \mathrm{~m}^{-2}$ on 9 July and coincided with the start of a Greenland-wide warm event. On 12 July, nearly the entire ice sheet surface was reported to melt (Nghiem et al., 2012), followed shortly after by the highest meltwater discharge in 

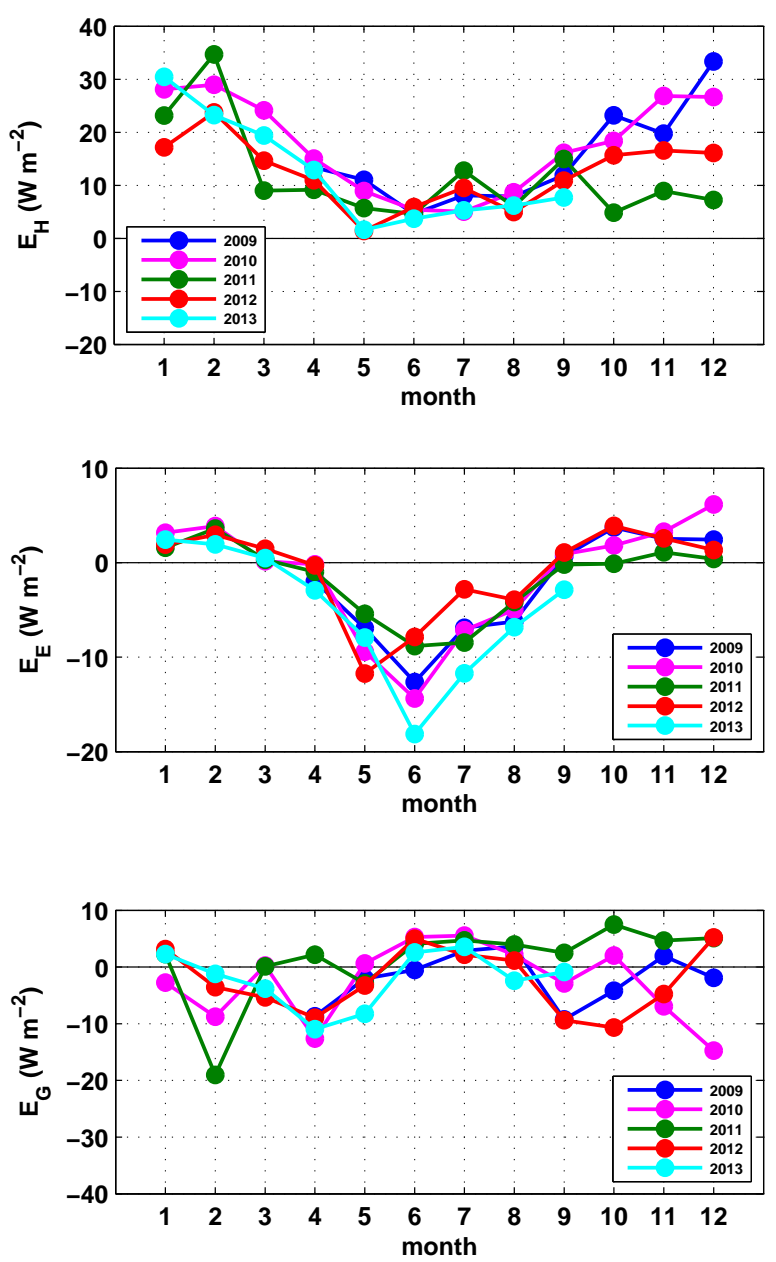

Figure 7. Seasonal cycles for the years 2009-2013 based on monthly averages of (a) sensible heat flux, (b) latent heat flux, and (c) subsurface heat flux.

56 years on 12 July 2012, as inferred by the partial destruction of a bridge constructed over the Watson River in Kangerlussuaq in 1956. At KAN_U, well above the long-term ELA, not only a strongly negative SMB was recorded in 2012, but it was the only year with a positive annual radiation budget $\left(E_{\mathrm{R}}=+4 \mathrm{~W} \mathrm{~m}^{-2}\right.$; Table 5).

$E_{\mathrm{H}}$ was largest during 2010 and smallest during 2011 (Table 5), the years of highest and lowest annual $T_{\mathrm{a}}$ respectively (Table 3). Sensible heat transfer toward the ice sheet surface was also low on average in 2012, owing to the cold winter months. The high July $2011 E_{\mathrm{H}}$ was due to warm air advection that occurred over a cold surface, yielding large nearsurface temperature gradients and sensible heat exchange (Fig. 7a). During summer 2013, when air temperatures remained relatively low, the ice sheet surface exhibited the lowest sensible heat gain compared to the other melt seasons. In all, $E_{\mathrm{H}}$ did not contribute to SEB interannual variability as much as the radiative components.
Table 5. Annual and summer (June-July-August) average energy fluxes at KAN_U $\left(\mathrm{W} \mathrm{m}^{-2}\right)$.

\begin{tabular}{lrrrrr}
\hline & $2009^{*}$ & 2010 & 2011 & 2012 & $2013^{* *}$ \\
\hline \multicolumn{5}{c}{ Annual averages } \\
\hline$E_{\mathrm{S}}^{\downarrow}$ & 155 & 153 & 150 & 145 & 151 \\
$E_{\mathrm{S}}^{\uparrow}$ & -125 & -121 & -121 & -110 & -119 \\
$E_{\mathrm{S}}^{\mathrm{Net}}$ & 30 & 32 & 29 & 35 & 32 \\
$E_{\mathrm{L}}^{\downarrow}$ & 207 & 224 & 205 & 223 & 212 \\
$E_{\mathrm{L}}^{\uparrow}$ & -246 & -262 & -239 & -254 & -248 \\
$E_{\mathrm{L}}^{\mathrm{Net}}$ & -39 & -38 & -34 & -31 & -36 \\
$E_{\mathrm{R}}$ & -9 & -6 & -5 & 4 & -4 \\
$E_{\mathrm{H}}$ & 17 & 18 & 12 & 12 & 14 \\
$E_{\mathrm{E}}$ & -2 & -1 & -2 & -1 & -3 \\
$E_{\mathrm{G}}$ & -2 & -3 & 1 & -2 & -2 \\
$E_{\mathrm{P}}$ & 0.004 & 0.006 & 0.009 & 0.012 & 0.005 \\
$E_{\mathrm{M}}$ & 4 & 8 & 6 & 13 & 5 \\
\hline & & Summer $(\mathrm{JJA})$ averages & \\
\hline$E_{\mathrm{S}}^{\downarrow}$ & 322 & 305 & 302 & 296 & 313 \\
$E_{\mathrm{S}}^{\uparrow}$ & -252 & -234 & -236 & -208 & -242 \\
$E_{\mathrm{S}}^{\mathrm{Net}}$ & 70 & 71 & 66 & 88 & 71 \\
$E_{\mathrm{L}}^{\downarrow}$ & 237 & 259 & 252 & 260 & 245 \\
$E_{\mathrm{L}}^{\uparrow}$ & -291 & -303 & -299 & -303 & -292 \\
$E_{\mathrm{L}}^{\mathrm{Net}}$ & -54 & -44 & -47 & -43 & -47 \\
$E_{\mathrm{R}}$ & 16 & 27 & 19 & 45 & 24 \\
$E_{\mathrm{H}}$ & 6 & 6 & 8 & 7 & 5 \\
$E_{\mathrm{E}}$ & -9 & -9 & -7 & -5 & -13 \\
$E_{\mathrm{G}}$ & 2 & 4 & 4 & 2 & 1 \\
$E_{\mathrm{P}}$ & 0.014 & 0.025 & 0.035 & 0.049 & 0.021 \\
$E_{\mathrm{M}}$ & 15 & 28 & 24 & 49 & 17 \\
\hline $\mathrm{A}_{\mathrm{n}}$ & & & & \\
\hline
\end{tabular}

* Average 2010-2013 for January, February, and March; ** average 2009-2012 for October, November, and December.

Summer $E_{\mathrm{E}}$ values are correlated with summer atmospheric pressure $(R=0.96)$, which influences the gradients in near-surface specific humidity and wind speed. During summer 2012, pressure and specific humidity were relatively high ( $811 \mathrm{hPa}$ and $3.7 \mathrm{~g} \mathrm{~kg}^{-1}$ respectively; Table 3), while the wind speed was reduced, thus contributing to the lowest absolute summer $E_{\mathrm{E}}$ with the lowest cooling rates due to evaporation/sublimation. The maximum latent heat loss that year occurred in May. Thereafter, the moisture content in the near-surface air became relatively large, with $E_{\mathrm{E}}$ decreasing in absolute value until July. Summer 2013 was conversely characterized by relatively low pressure and specific humidity ( $804 \mathrm{hPa}$ and $2.8 \mathrm{~g} \mathrm{~kg}^{-1}$ respectively) resulting in high evaporation/sublimation rates especially in June and July (Fig. 7b). 
Monthly $E_{\mathrm{G}}$ values were small and displayed small interannual variability, especially in summer. The summers of 2010 and 2011 exhibited the most positive $E_{\mathrm{G}}$ as a consequence of substantial refreezing (Fig. 7c), which influenced near-surface firn temperature gradients. Summer $E_{\mathrm{G}}$ in 2009 and 2013 (Table 5) was lower due to the moderate melt seasons of smaller duration. Summer $E_{\mathrm{G}}$ was lower in 2012 due to both a warm ice sheet surface conducting heat into the firn and the absence of refreezing.

The melt rates in 2009 and 2013 were similar. In both years the largest monthly $E_{\mathrm{M}}$ occurred in July and did not exceed $30 \mathrm{~W} \mathrm{~m}^{-2}$ (Fig. 8). $E_{\mathrm{M}}$ peaked similarly in 2010 and 2011 , in June reaching about $20 \mathrm{~W} \mathrm{~m}^{-2}$ and in July exceeding $35 \mathrm{~W} \mathrm{~m}^{-2}$. May and August 2010 exhibited significant melt in response to the warm atmospheric conditions (Van As et al., 2012). Both 2010 and 2012 exhibited significant melt in May $\left(10 \mathrm{~W} \mathrm{~m}^{-2}\right)$. During summer 2012, $E_{\mathrm{M}}$ far exceeded all other years, with a July value of $68 \mathrm{~W} \mathrm{~m}^{-2}$, leading to the largest ablation reported in Table 4.

The radiative fluxes dominate the interannual variability of melt at KAN_U, with variations in $E_{\mathrm{L}}^{\mathrm{Net}}$ being most influential over the amount of available $E_{\mathrm{M}}$ in the years 2009-2011 and 2013. In 2012, it was the large $E_{\mathrm{S}}^{\mathrm{Net}}$ that mainly contributed to the melt anomaly.

\subsection{Melt-albedo feedback}

Figure 9a, which depicts total monthly surface energy exchanges throughout the study period, illustrates that $E_{\mathrm{S}}^{\mathrm{Net}}$ and $E_{\mathrm{L}}^{\text {Net }}$ dominate the SEB from May to September, while $E_{\mathrm{L}}^{\text {Net }}$ and $E_{\mathrm{H}}$ dominate the SEB during the remainder of the year. During the years exclusive of 2012 considered here (2009, 2010, 2011, and 2013), the total summer energy input to the ice sheet surface was $620-650 \mathrm{MJ} \mathrm{m}^{-2}$ each year. During all years, the energy input peaked in July. For example, in July 2010 the total energy input reached $246 \mathrm{MJ} \mathrm{m}^{-2}$. By contrast, in 2012, the total summer energy input exceeded $770 \mathrm{MJ} \mathrm{m}^{-2}$, and in July it reached $304 \mathrm{MJ} \mathrm{m}^{-2}$. The 2012 total energy used for melt was $414 \mathrm{MJ} \mathrm{m}^{-2}$ (65\% higher than in 2010), of which $183 \mathrm{MJ} \mathrm{m}^{-2}$ was used for melt in July. Figure $9 \mathrm{~b}$ illustrates the simulated mass fluxes at the ice sheet surface (note the different $y$ axis scales for positive and negative values). A total of $40 \mathrm{~kg} \mathrm{~m}^{-2}$ of mass loss occurs on average by the sum of sublimation and evaporation during spring and summer. Conversely, deposition amounts to $10 \mathrm{~kg} \mathrm{~m}^{-2}$ each winter season. The total snowfall from April 2009 until September 2013 amounted $\sim 1500 \mathrm{~kg} \mathrm{~m}^{-2}$ (also Table 4). Up to the end of May 2012, all meltwater had accumulated internally through percolation into the firn, adding mass of $1158 \mathrm{~kg} \mathrm{~m}^{-2}\left(1020 \mathrm{~kg} \mathrm{~m}^{-2}\right.$ from snowfall and $138 \mathrm{~kg} \mathrm{~m}^{-2}$ from rainfall). Due to an ice layer blocking vertical percolation in summer 2012, $444 \mathrm{~kg} \mathrm{~m}^{-2}$ ran off, removing approximately $38 \%$ of accumulated mass since April 2009.

The total amount of meltwater generated at the ice sheet surface, equivalent to the sum of run-off and refreezing mi-

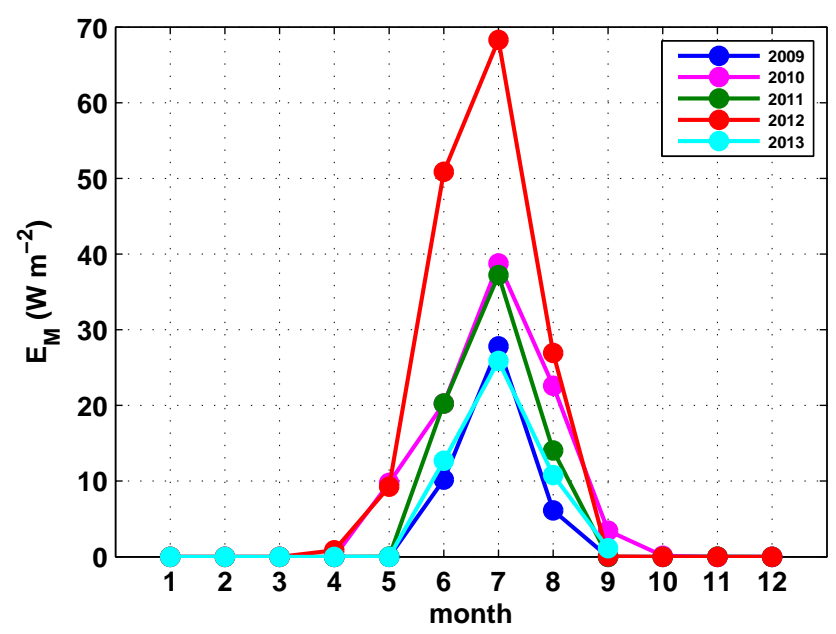

Figure 8. Seasonal cycle for the years 2009-2013 based on monthly averages of energy consumed by melt.

nus rainfall, amounted $1232 \mathrm{~kg} \mathrm{~m}^{-2}$ in 2012 . As the calculated surface ablation was $860 \mathrm{~kg} \mathrm{~m}^{-2}$ (Table 4), $30 \%$ $\left(372 \mathrm{~kg} \mathrm{~m}^{-2}\right)$ of the produced meltwater was melted more than once during the ablation season. This suggests that $416 \mathrm{~kg} \mathrm{~m}^{-2}$ (48\% of the total ablation or $34 \%$ of the produced meltwater) was effectively retained in near-surface firn layers.

The first year on record during which surface ablation exceeded accumulation from the preceding winter at KAN_U was 2010 (Table 4; Van de Wal et al., 2012). Even though atmospheric temperatures were high and the impact on ablation was large in 2010, the response of the snow surface was much larger in 2012, when ablation was more than 3 times larger than the accumulation. In 2012, albedo decreased to $\sim 0.7$ by mid-June (Charalampidis and van As, 2015), implying substantial metamorphosis of the snow surface, while in all other years this albedo was reached only in July or August. The albedo reduced even more on 10 July to $\sim 0.6$, signifying the saturation of the ice sheet surface and the exposure of thick firn. Until 6 August, the albedo value corresponded to that of soaked facies close to the snow/firn line (Cuffey and Paterson, 2010). It should be noted that snowfall events increased the albedo during several periods in the summer season (Charalampidis and van As, 2015).

To quantify the impact of a relatively dark ice sheet surface on the SEB, the average annual cycle in albedo of all years excluding 2012 was used to replace the low 2012 albedo in dedicated sensitivity analysis. Figure 10a shows the albedo anomaly of 2012, which resulted in enhanced ablation in late May/early June (Fig. 10b). At the end of August, the ice sheet surface lowered an additional $0.64 \mathrm{~m}$ due to $58 \%$ more melt energy compared to a situation with average albedo. The excess $E_{\mathrm{M}}$ from the melt-albedo feedback amounted to $152 \mathrm{MJ} \mathrm{m}^{-2}$, while the excess $E_{\mathrm{S}}^{\text {Net }}$ supplied was $213 \mathrm{MJ} \mathrm{m}^{-2}$ (Fig. 10c). The remaining $E_{\mathrm{S}}^{\mathrm{Net}}$ was con- 


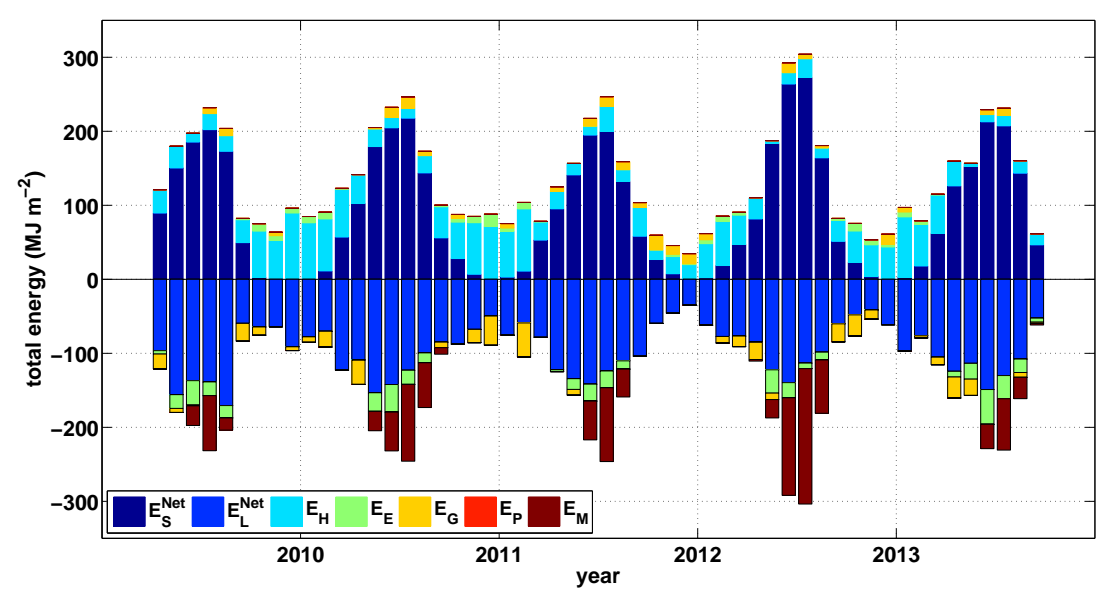

(a)

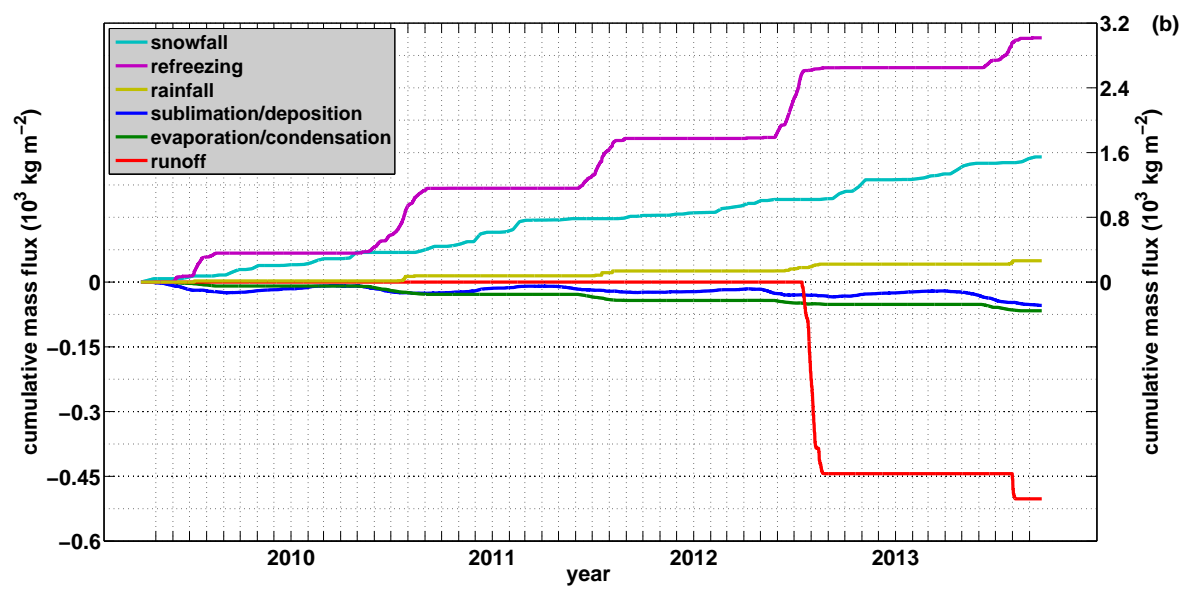

Figure 9. (a) Total energy per unit surface area. (b) Cumulative fluxes of all mass components. Note the different $y$ scales in (b).
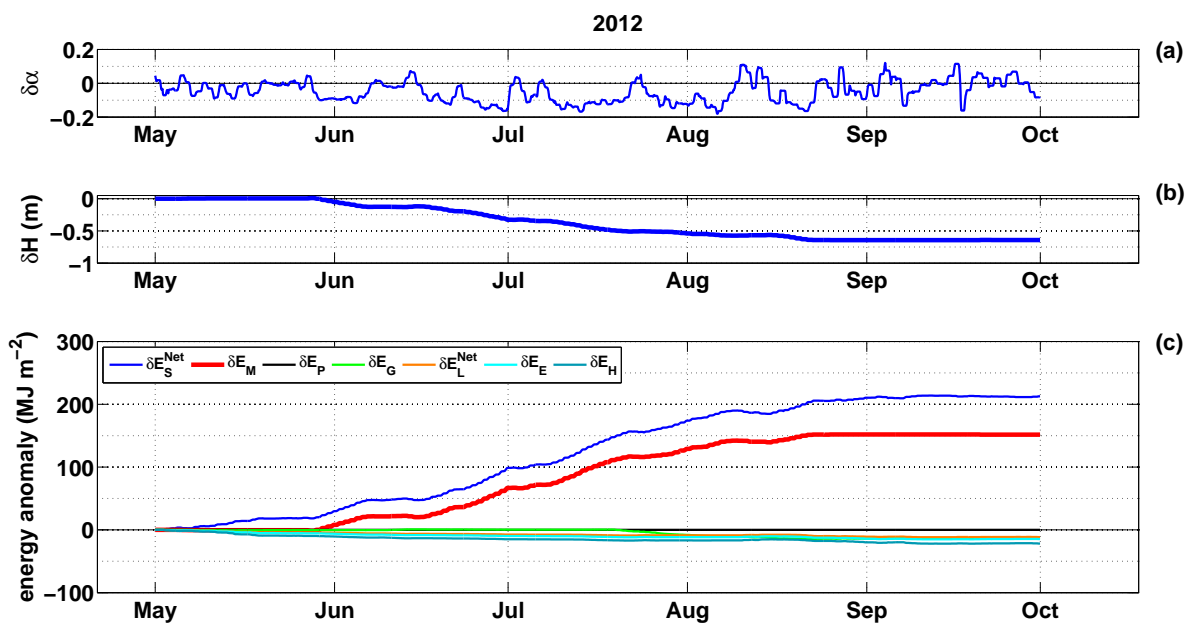

Figure 10. (a) Albedo anomaly in 2012 measured by KAN_U for the months May-September; (b) simulated relative surface height anomaly; (c) simulated cumulative energy anomalies for all contributing fluxes. 
sumed by other fluxes, primarily $E_{\mathrm{H}}$. As the total surface ablation of 2012 was $1.78 \mathrm{~m}$ of surface height change (Fig. 2) the remaining $1.14 \mathrm{~m}$ was primarily due to the warm atmospheric conditions and similar to $2010(1.21 \mathrm{~m})$. This sensitivity analysis implies that the location would have experienced a negative SMB in 2012 even without the melt-albedo feedback.

\section{Discussion}

\subsection{Uncertainties}

Model performance is limited by the accuracy of the instruments of KAN_U as given in Table 1. The radiometer uncertainties are the largest, based on what is reported by the manufacturer ( $10 \%$ for daily totals, although this is likely to be an overestimate; Van den Broeke et al., 2004). Nevertheless, the accurate simulation of surface temperature and snow ablation rates (Fig. 2) throughout the period of observations provides confidence in both the measurements and the model.

The model exhibits considerable sensitivity to the subsurface calculations, suggesting importance of pore volume and firn temperature, and how much more complicated SEB calculations are in the lower accumulation area than for bare ice in the ablation area. The model is able to capture the seasonal variations of temperature in the firn and calculated temperatures are commonly within $3.6^{\circ} \mathrm{C}$ of those measured with an average of $-0.3{ }^{\circ} \mathrm{C}$ (Fig. 11a). The shallow percolation of a wetting front in the firn is estimated at depths of 1-3 $\mathrm{m}$ in the years 2009 and 2013 (Fig. 11b), while in the years of larger melt, pore volume until $10 \mathrm{~m}$ depth is affected, possibly overestimating the percolation depth given the relative temperature buildup in the simulated firn below roughly $5 \mathrm{~m}$ depth (Fig. 11a; Charalampidis et al., 2016). In particular for 2012, available simulated pore volume at $\sim 6 \mathrm{~m}$ is significantly affected by meltwater that percolates below the formed thick ice layer, which may indicate that the run-off threshold of a $6 \mathrm{~m}$ thick ice layer is an overestimate, highlighting the need for a better run-off criterion. Further investigation on this criterion and inclusion of water content held in the firn by capillary forces, saturation of the surface, and proximity of impermeable ice to the surface is necessary.

The fact that the subsurface calculations are initialized in 2009 by use of vertically shifted firn densities from a 2012 core does not influence the calculation of the surface energy fluxes and thus the outcome of this paper. Importantly, the timing that simulated run-off occurred in July 2012 is in agreement with satellite observations due to the run-off criterion, thereby providing confidence in realistic calculation of $E_{\mathrm{G}}$.

Although the subsurface calculations are on a vertical grid of $10 \mathrm{~cm}$ (see also Sect. 2.3), there is a progressive loss of detail in the density profile through time due to the interpo- lation scheme that shifts the column vertically when it needs to account for surface height variations (Fig. 11c). Increased spatial resolution requires a finer temporal resolution to avoid model instability. Although the calculated SEB would be unaffected, we accepted the loss of detail in density because increasing the spatial and temporal resolution would result in substantially increased computational time. Nevertheless, during each melt season, when it is important that refreezing is accounted for, no loss of detail is expected near the surface since the column is shifted almost continuously upward.

Rainfall is known to occur during summer on the higher elevations of the ice sheet (Doyle et al., 2015). The exact amount is unknown as in situ measurements for precipitation are rare and difficult to acquire on the ice sheet. Therefore, the rainfall calculated by our model should be considered a first-order estimate. Nevertheless, the amount of rain is expected to be small and its effect on the SEB is negligible, as shown by the model results.

It is possible that other factors than heat-induced snow metamorphism and the presence of surface water contributed to the 2012 albedo anomaly. Such could be aerosol particles or impurities at the snow surface, effectively reducing its albedo (Doherty et al., 2013). Also, in cases of extreme melt, microbial activity can develop at the ice sheet surface with the subsequent production of a dark-coloured pigment (Benning et al., 2014).

\subsection{Long-term perspective in temperature and albedo}

The Kangerlussuaq airport air temperature record since 1976 was used to provide a temporal perspective to the KAN_U air temperature in recent years (Fig. 12). The standard deviations reveal variability during the winter period of more than $10^{\circ} \mathrm{C}$ while for the months of July and August standard deviations are $\sim 2.0^{\circ} \mathrm{C}$. The temperature measurements reveal that the region has been warming on average starting in 1996 (not shown). Figure 12c illustrates this for 20002013; e.g. the summers (JJA) were $1.2^{\circ} \mathrm{C}$ warmer than in the reference period 1976-1999. The warm 2010 and 2012 summers have an anomaly value of +1.9 and $+1.8^{\circ} \mathrm{C}$ respectively. The high temperatures in recent years are most apparent for June when in 10 out of 14 years the 1976-1999 standard deviation is exceeded. A further increase of the regional temperatures, as anticipated by climate models, will likely further increase the frequency of large melt events and the extent of each melt season, leading to conditions similar to or more extreme than in 2012 (McGrath et al., 2013).

The MOD10A1 time series from the years 2000-2013 shows an albedo decrease of $0.05-0.10$ during the 14 years of measurements in response to the increased temperatures (Fig. 13). In particular, May albedo reached record low values in 2010 and 2012. July albedo is considerably lower in the years 2007-2013 than it was in the first half of the record. The exceptional surface conditions in July 2012 were also captured by MODIS with the lowest monthly albedo $(\sim 0.6)$ 

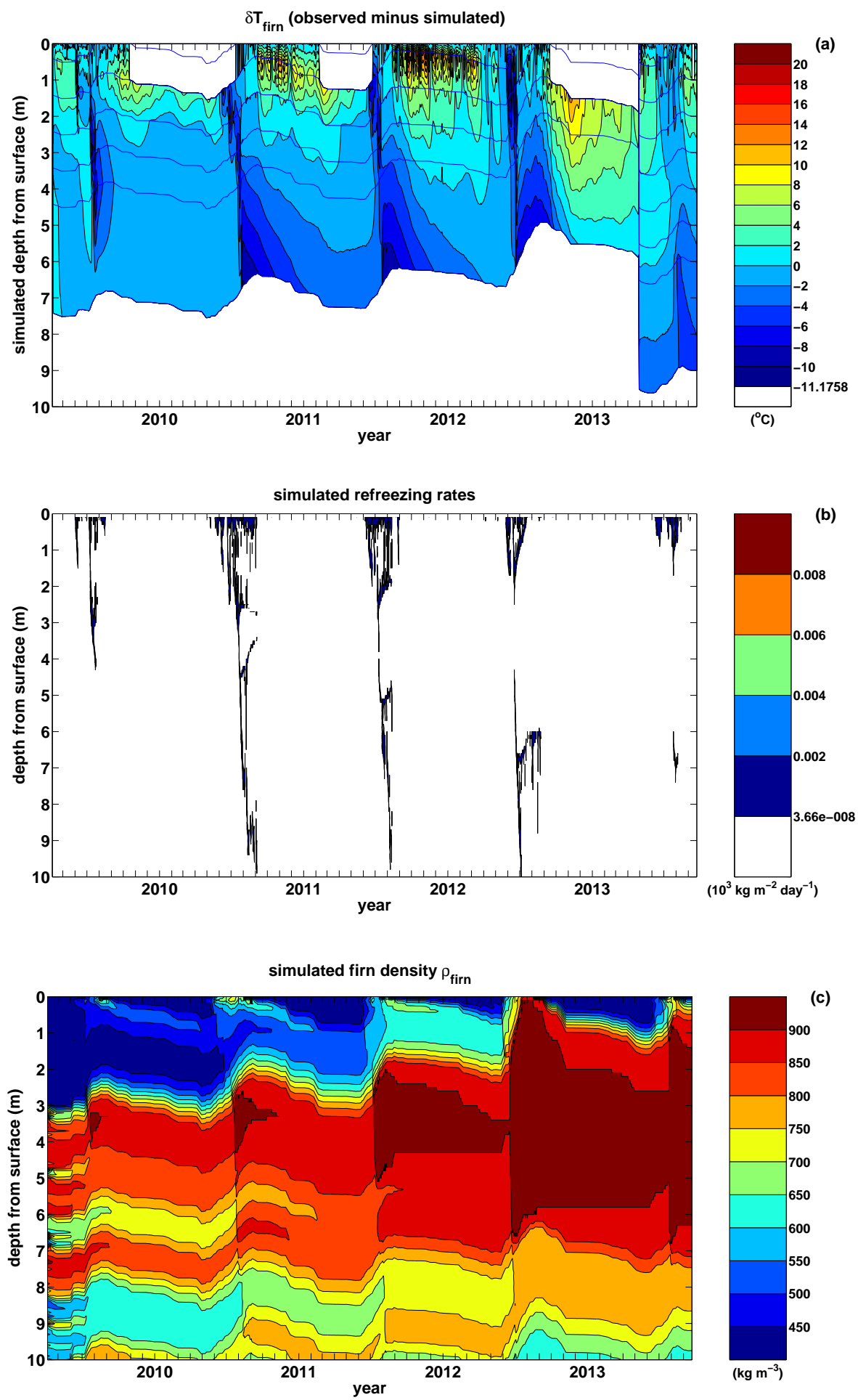

Figure 11. (a) Difference between firn temperature measured by the KAN_U thermistor string and simulated firn temperature. The blue lines indicate the position of the thermistors below the surface. The white areas near the surface are due to surfaced thermistors. Note that the thermistor string was replaced by a new one drilled on 28 April 2013. (b) Simulated refreezing rates. (c) Simulated firn density. 

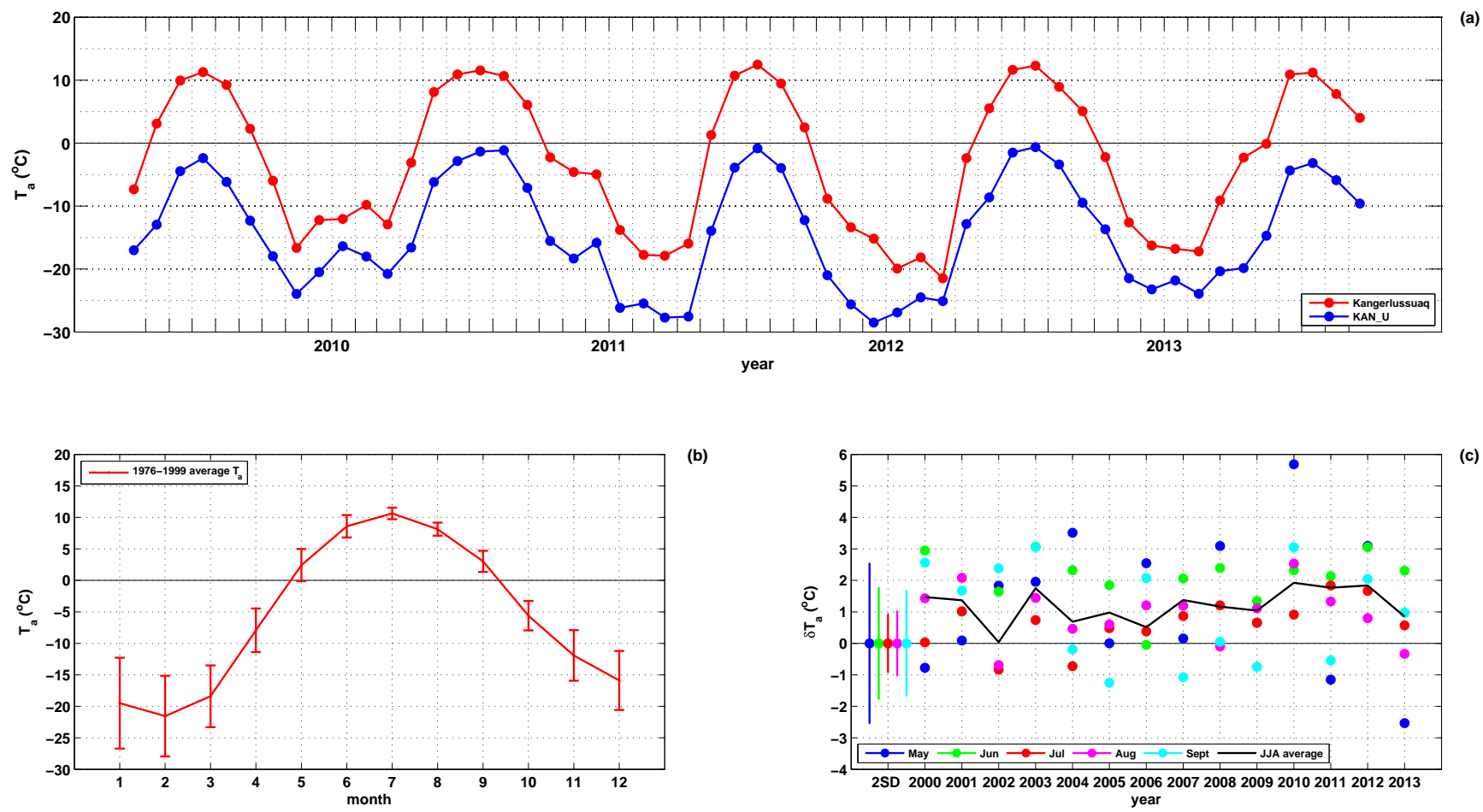

(b)

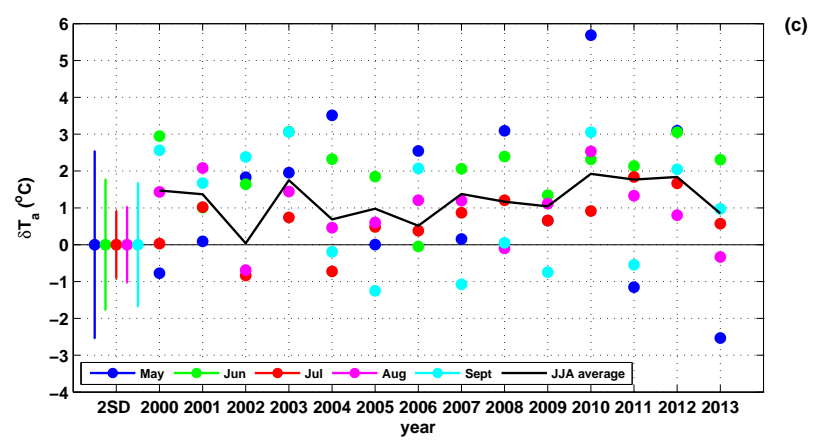

Figure 12. (a) Monthly air temperature at Kangerlussuaq and at KAN_U. Correlation coefficients $(R)$ : 0.97 for the extent of the KAN_U data and 0.66-0.99 for the months individually, with the minimum being January. (b) Monthly reference period (1976-1999) air temperature at Kangerlussuaq. (c) Monthly (May to September) and summer (June-July-August average) air temperature anomalies at Kangerlussuaq for the years 2000-2013. Error bars indicate 2 standard deviations.

of the time series. The albedo in August is generally higher than in July due to snowfall, but the values remain sufficiently low to enhance melt. We note that part of the MODIS based albedo decrease could be the result of the declining instrument sensitivity of the Terra MODIS sensor (Wang et al., 2012; Lyapustin et al., 2014) though updated (through 2014) comparisons between MOD10A1 and ground observations from GC-Net data (Box et al. (2012); not shown) do not indicate an obvious or statistically significant difference.

Increased meltwater infiltration into the firn during events of increased melt has led to the formation of thick, nearsurface ice lenses between 2 and $7 \mathrm{~m}$, judging from the 2012 firn core (Machguth et al., 2015). This contrasts with the aquifers (i.e. liquid water storage) that are observed in the firn in southeast Greenland (Forster et al., 2013; Koenig et al., 2013; Kuipers Munneke et al., 2014). The southwestern ice sheet receives about one-third of the annual precipitation received in the southeast (Ettema et al., 2009). This results in reduced thermal insulation of the infiltrated water as well as reduced generation of pore volume. The subsequent shallow refreezing during recent years of enhanced melt has led to the formation of thick impermeable ice, ultimately enabling run-off in 2012 (Machguth et al., 2015).

The DMI measurements indicate that 2009 is representative of the reference period 1976-1999 (Fig. 11c; Van As et al., 2012). With respect to summer 2009, the radiation budget in summer 2010 was higher due to lower $E_{\mathrm{L}}^{\mathrm{Net}}$ (Table 5; Sect. 3.3). In summer 2012, $E_{\mathrm{L}}^{\mathrm{Net}}$ was the same while $E_{\mathrm{S}}^{\mathrm{Net}}$ was larger than in 2010 . Most of this $E_{\mathrm{S}}^{\text {Net }}$ excess was consumed by melting (Sect. 3.4). The melt-albedo feedback (Box et al., 2012) will contribute to the rise of the ELA in a warming climate (Fettweis, 2007; Van de Wal et al., 2012), and might transform the lower accumulation area into superimposed ice if warming prevails. We have shown that the melt-albedo feedback makes that warm summers can have great impact on melt and run-off in the lower accumulation area. Our results suggest that if warm atmospheric conditions persist in the future, the additional input of solar radiation at the ice sheet surface will be of higher importance to surface changes than atmospheric warming.

\section{Conclusions}

We used 5 years of automatic weather station measurements to characterize the prevailing meteorology and surface energy fluxes at a location in the lower accumulation area of the southwestern Greenland ice sheet. The analysis revealed that the interannual variability was largely governed by the radiative components, primarily from net longwave radiation. The main contributor to melt is absorbed solar radiation. In all but 


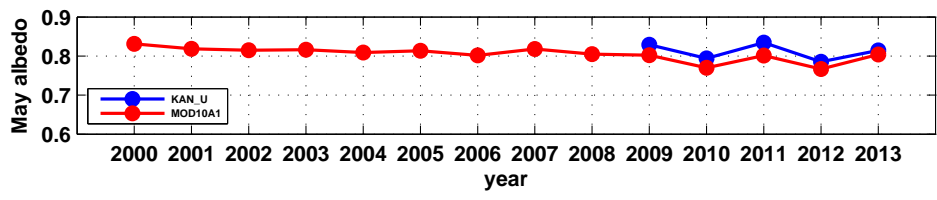

(a)

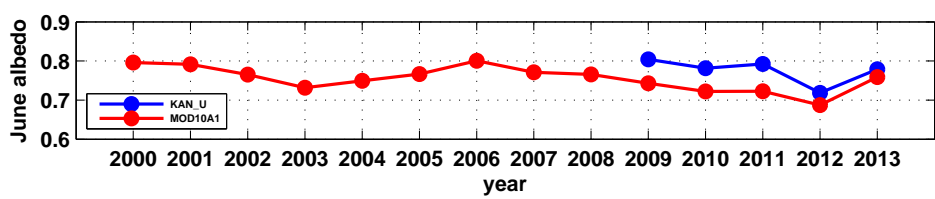

(b)

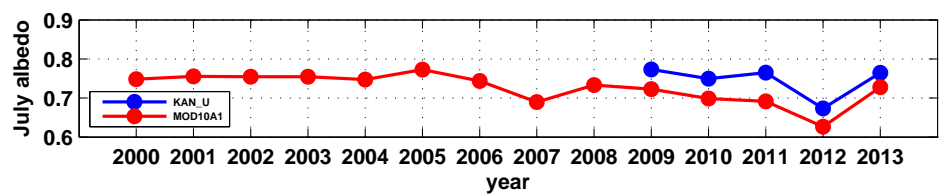

(c)

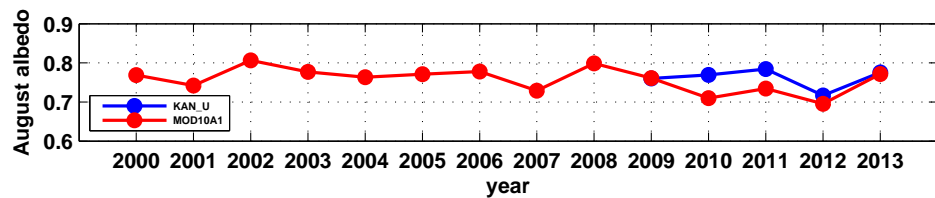

(d)

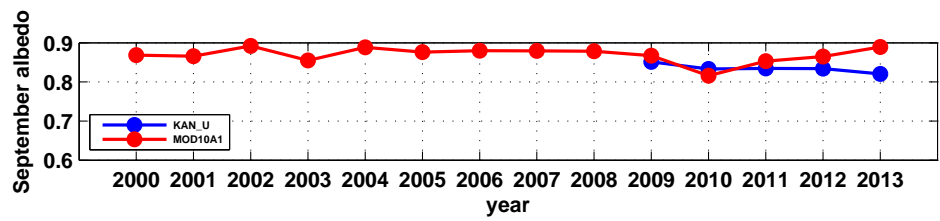

(e)

Figure 13. Eleven-day Gaussian filtered nearest neighbour $5 \times 5 \mathrm{~km}$ MOD10A1 albedo (2000-2013) and KAN_U (2009-2013) albedo for the months: (a) May $\left(R=0.91,(\Delta \alpha)_{\mathrm{avg}}=-0.02, \mathrm{RMSD}=0.02\right)$, (b) June $\left(R=0.77,(\Delta \alpha)_{\mathrm{avg}}=-0.05\right.$, RMSD $\left.=0.05\right)$, (c) July $\left(R=0.95,(\Delta \alpha)_{\mathrm{avg}}=-0.05, \mathrm{RMSD}=0.05\right),(\mathbf{d})$ August $\left(R=0.60,(\Delta \alpha)_{\mathrm{avg}}=-0.03, \mathrm{RMSD}=0.04\right)$, and (e) September $(R=-0.19$, $\left.(\Delta \alpha)_{\mathrm{avg}}=0.02, \mathrm{RMSD}=0.04\right)$.

1 year of observations, however, solar radiation did not control surface mass balance variability. This was not the case during the 2012 melt season, when the area attained unusually low albedo values $(<0.7)$ owing to large melt and the subsequent exposure of water-saturated, high-density firn. The consequent enhanced solar absorption along with warm atmospheric conditions resulted in intensified melt during the most negative surface mass budget year since 1994 and presumably since at least 1976 given the Kangerlussuaq temperature record. A sensitivity test with our energy balance model indicated that the melt-albedo feedback contributed an additional $58 \%\left(152 \mathrm{MJ} \mathrm{m}^{-2}\right)$ to melt energy in 2012, though increased atmospheric temperatures alone would have also yielded a negative surface mass budget.

Percolation of meltwater within snow and firn is generally considered to refreeze in firn at $1840 \mathrm{~m}$ a.s.l. on the ice sheet, which prevents run-off and therefore limits Greenland's contribution to sea level rise. This concept is applicable to all higher elevation regions of the ice sheet where there is moderate melt and deep percolation is possible. However, the lower accumulation area of the southwestern ice sheet showed high sensitivity to the warm atmosphere in 2012, primarily due to the relatively low precipitation in the region, which prevents the timely replenishment of saturated pore volume in the near-surface firn under extreme melting conditions. Water retained in the firn can lead to substantial increase in density due to refreezing, which in warm years may not only function as a mechanism to block percolation but also lower the surface albedo and enhance melt, accelerating the transformation of a lower accumulation area underlain by firn into an ablation area underlain by superimposed ice. This highlights the importance of accurately modelling percolation and refreezing within the firn in order to best estimate the sea level rise contribution associated with Greenland ice sheet meltwater production.

Acknowledgements. We are grateful to Xavier Fettweis and an anonymous reviewer for constructive comments. We also thank Andreas Mikkelsen for snow density measurements and Robert Fausto, Filippo Calì Quaglia, and Daniel Binder for valuable discussions. The KAN_U weather station was funded by the nuclear waste management organizations in Sweden (Svensk Kärnbränsle- 
hantering $\mathrm{AB}$ ), Finland (Posiva Oy), and Canada (NWMO) through the Greenland Analogue Project (GAP Sub-Project A). It is operated by the Geological Survey of Denmark and Greenland (GEUS) with 2009-2012 logistical, technical, and manpower support from Aberystwyth University funded through the UK Natural Environmental Research Council (NERC grant NE/G005796/1), a Royal Geographical Society (RGS) Gilchrist Fieldwork Award, and an Aberystwyth University doctoral scholarship. Technical and salary support was received from the Programme for Monitoring of the Greenland Ice Sheet (PROMICE), launched and funded by the Danish Energy Agency (Energistyrelsen) under the Danish Ministry of Energy, Utilities and Climate and within the Danish Cooperation for Environment in the Arctic (DANCEA). We further acknowledge support from the Netherlands Polar Programme of the Netherlands Organization for Scientific Research (NWO). This is a PROMICE publication and contribution number 52 of the Nordic Centre of Excellence SVALI, "Stability and Variations of Arctic Land Ice", funded by the Nordic Top-level Research Initiative (TRI).

Edited by: E. Hanna

\section{References}

Ahlstrøm, A. P., and the PROMICE project team: A new programme for monitoring the mass loss of the Greenland ice sheet, Geol. Surv. Denmark Greenland Bull., 15, 61-64, 2008.

Ambach, W.: The influence of cloudiness on the net radiation balance of a snow surface with high albedo, J. Glaciol., 13, 73-84, 1974.

Andreas, E. L.: A theory for the scalar roughness and the scalar transfer coefficients over snow and sea ice, Bound.-Lay. Meteorol., 38, 159-184, doi:10.1007/BF00121562, 1987.

Bamber, J. L., Griggs, J. A., Hurkmans, R. T. W. L., Dowdeswell, J. A., Gogineni, S. P., Howat, I., Mouginot, J., Paden, J., Palmer, S., Rignot, E., and Steinhage, D.: A new bed elevation dataset for Greenland, The Cryosphere, 7, 499-510, doi:10.5194/tc-7499-2013, 2013.

Bennartz, R., Shupe, M. D., Turner, D. D., Walden, V. P., Steffen, K., Cox, C. J., Kulie, M. S., Miller, N. B., and Pettersen, C.: July 2012 Greenland melt extent enhanced by low-level liquid clouds, Nature, 496, 83-86, doi:10.1038/Nature12002, 2013.

Benning, L. G., Anesio, A. M., Lutz, S., and Tranter, M.: Biological impact on Greenland's albedo, Nat. Geosci., 7, 691, doi:10.1038/ngeo2260, 2014.

Bøggild, C. E., Brandt, R. E., Brown, K. J., and Warren, S. G.: The ablation zone in northeast Greenland: Ice types, albedos, and impurities, J. Glaciol., 56, 101-113, doi:10.3189/002214310791190776, 2010.

Box, J. E., Fettweis, X., Stroeve, J. C., Tedesco, M., Hall, D. K., and Steffen, K.: Greenland ice sheet albedo feedback: thermodynamics and atmospheric drivers, The Cryosphere, 6, 821-839, doi:10.5194/tc-6-821-2012, 2012.

Cappelen, J.: Weather Observations from Greenland 1958-2012, Technical Report 13-11, Danish Meteorological Institute, Ministry of Climate and Energy, Copenhagen, 23 pp., 2013.
Charalampidis, C. and van As, D.: Observed melt-season snowpack evolution on the Greenland ice sheet, Geol. Surv. Denmark Greenland Bull., 33, 65-68, 2015.

Charalampidis, C., van As, D., Colgan, W. T., Fausto, R. S., MacFerrin, M., and Machguth, H.: Thermal tracing of retained meltwater in the lower accumulation area of the southwestern Greenland ice sheet, Ann. Glaciol., 57, doi:10.3189/2016AoG72A003, 2016.

Citterio, M., van As, D., Ahlstrøm, A. P., Andersen, M. L., Andersen, S. B., Box, J. E., Charalampidis, C., Colgan, W. T., Fausto, R. S., Nielsen, S., and Veicherts, M.: Automatic weather stations for basic and applied glaciological research, Geol. Surv. Denmark Greenland Bull., 33, 69-72, 2015.

Cuffey, K. M. and Paterson, W. S. B.: The physics of glaciers, Elsevier, Oxford, UK, 693 pp., 2010.

Doherty, S. J., Grenfell, T. C., Forsström, S., Hegg, D. L., Brandt, R. E., and Warren, S. G.: Observed vertical redistribution of black carbon and other insoluble light-absorbing particles in melting snow, J. Geophys. Res.-Atmos., 118, 5553-5569, doi:10.1002/jgrd.50235, 2013.

Doyle, S. H., Hubbard, A. L., van de Wal, R. S. W., Box, J. E., van As, D., Scharrer, K., Meierbachtol, T. W., Smeets, C. J. P. P., Harper, J. T., Johansson, E., Mottram, R. H., Mikkelsen, A. B., Wilhelms, F., Patton, H., Christoffersen, P., and Hubbard, B.: Amplified melt and flow of the Greenland ice sheet driven by late-summer cyclonic rainfall, Nat. Geosci., 8, 647653, doi:10.1038/ngeo2482, 2015.

Enderlin, E. M., Howat, I. M., Jeong, S., Noh, M.-J., van Angelen, J. H., and van den Broeke, M. R.: An improved mass budget for the Greenland ice sheet, Geophys. Res. Lett., 41, 866-872, doi:10.1002/2013GL059010, 2014.

Ettema, J., van den Broeke, M. R., van Meijgaard, E., van de Berg, W. J., Bamber, J. L., Box, J. E., and Bales, R. C.: Higher surface mass balance of the Greenland ice sheet revealed by highresolution climate modeling, Geophys. Res. Lett., 36, L12501, doi:10.1029/2009GL038110, 2009.

Ettema, J., van den Broeke, M. R., van Meijgaard, E., and van de Berg, W. J.: Climate of the Greenland ice sheet using a highresolution climate model - Part 2: Near-surface climate and energy balance, The Cryosphere, 4, 529-544, doi:10.5194/tc-4529-2010, 2010.

Fettweis, X.: Reconstruction of the 1979-2006 Greenland ice sheet surface mass balance using the regional climate model MAR, The Cryosphere, 1, 21-40, doi:10.5194/tc-1-21-2007, 2007.

Forster, R. R., Box, J. E., van den Broeke, M. R., Miège, C., Burgess, E. W., van Angelen, J. H., Lenaerts, J. T. M., Koenig, L. S., Paden, J., Lewis, C., Gogineni, S. P., Leuschen, C., and McConnell, J. R.: Extensive liquid melt water storage in firn within the Greenland ice sheet, Nat. Geosci., 7, 95-98, doi:10.1038/NGEO2043, 2013.

Greuell, W.: Melt water accumulation on the surface of the Greenland ice sheet: Effect on albedo and mass balance, Geograf. Ann. A, 82, 489-498, doi:10.1111/j.0435-3676.2000.00136.x, 2000.

Greuell, W., Denby, B., van de Wal, R. S. W., and Oerlemans, J.: Correspondance. 10 years of mass- balance measurements along a transect near Kangerlussuaq, central West Greenland, J. Glaciol., 47, 157-158, 2001. 
Hanna, E., Fettweis, X., Mernild, S. H., Cappelen, J., Ribergaard, M. H., Shuman, C. A., Steffen, K., Wood, L., and Mote, T. L.: Atmospheric and oceanic climate forcing of the exceptional Greenland ice sheet surface melt in summer 2012, Int. J. Climatol., 34, 1022-1037, doi:10.1002/joc.3743, 2014.

Harper, J., Humphrey, N., Pfeffer, W. T., Brown, J., and Fettweis, X.: Greenland ice-sheet contribution to sea-level rise buffered by melt water storage in firn, Nature, 491, 240-243, doi:10.1038/nature11566, 2012.

Henneken, E. A. C., Bink, N. J., Vugts, H. F., Cannemeijer, F., and Meesters, A. G. C. A.: A case study of the daily energy balance near the equilibrium line on the Greenland ice sheet, Global Planet. Change, 9, 69-78, doi:10.1016/0921-8181(94)90008-6, 1994.

Huybrechts, P. and de Wolde, J.: The dynamic response of the Greenland and Antarctic ice sheets to multiple-century climatic warming, J. Climate, 12, 2169-2188, doi:10.1175/15200442(1999)012<2169:TDROTG>2.0.CO;2, 1999.

Huybrechts, P., Goelzer, H., Janssens, I., Driesschaert, E., Fichefet, T., Goosse, H., and Loutre, M.-F.: Response of the Greenland and Antarctic Ice Sheets to Multi-Millennial Greenhouse Warming in the Earth System Model of Intermediate Complexity LOVECLIM, Surv. Geophys., 32, 397-416, doi:10.1007/s10712-0119131-5, 2011.

Illangasekare, T. H., Rodney Jr., J. W., Meier, M. F., and Pfeffer, W. T.: Modeling of melt water infiltration in subfreezing snow, Water Resour. Res., 26, 1001-1012, doi:10.1029/WR026i005p01001, 1990.

Koenig, L. S., Miège, C., Forster, R. R., and Brucker, L.: Initial in situ measurements of perennial melt water storage in the Greenland firn aquifer, Geophys. Res. Lett., 41, 81-85, doi:10.1002/2013GL058083, 2013.

Kuipers Munneke, P., Ligtenberg, S. R. M., van den Broeke, M. R., van Angelen, J. H., and Forster, R. R.: Explaining the presence of perennial liquid water bodies in the firn of the Greenland Ice Sheet, Geophys. Res. Lett., 41, 476-483, doi:10.1002/2013GL058389, 2014.

Lenaerts, J. T. M., Smeets, C. J. P. P., Nishimura, K., Eijkelboom, M., Boot, W., van den Broeke, M. R., and van de Berg, W. J.: Drifting snow measurements on the Greenland Ice Sheet and their application for model evaluation, The Cryosphere, 8, 801814, doi:10.5194/tc-8-801-2014, 2014.

Lyapustin, A., Wang, Y., Xiong, X., Meister, G., Platnick, S., Levy, R., Franz, B., Korkin, S., Hilker, T., Tucker, J., Hall, F., Sellers, P., Wu, A., and Angal, A.: Scientific impact of MODIS C5 calibration degradation and C6+ improvements, Atmos. Meas. Tech., 7, 4353-4365, doi:10.5194/amt-7-4353-2014, 2014.

Machguth, H., MacFerrin, M., van As, D., Box, J. E., Charalampidis, C., Colgan, W. T., Fausto, R. S., Meijer, H. A. J., MosleyThompson, E., and van de Wal, R. S. W.: Greenland meltwater storage in firn limited by near-surface ice formation, Nat. Clim. Change, in press, 2015.

MacWhorter, M. A. and Weller, R. A.: Error in measurements of incoming shortwave radiation made from ships and buoys, J. Atmos. Ocean. Tech., 8, 108-117, doi:10.1175/15200426(1991)008<0108:EIMOIS>2.0.CO;2, 1991.

McGrath, D., Colgan, W., Bayou, N., Muto, A., and Steffen, K.: Recent warming at Summit, Greenland: Global con- text and implications, Geophys. Res. Lett., 40, 2091-2096, doi:10.1002/grl.50456, 2013.

Nghiem, S. V., Hall, D. K., Mote, T. L., Tedesco, M., Albert, M. R., Keegan, K., Shuman, C. A., DiGirolamo, N. E., and Neumann, G.: The extreme melt across the Greenland ice sheet in 2012, Geophys. Res. Lett., 39, L20502, doi:10.1029/2012GL053611, 2012.

Shepherd, A., Ivins, E. R., A, G., Barletta, V. R., Bentley, M. J., Bettadpur, S., Briggs, K. H., Bromwich, D. H., Forsberg, R., Galin, N., Horwath, M., Jacobs, S., Joughin, I., King, M. A., Lenaerts, J. T. M., Li, J., Ligtenberg, S. R. M., Luckman, A., Luthcke, S. B., McMillan, M., Meister, R., Milne, G., Mouginot, J., Muir, A., Nicolas, J. P., Paden, J., Payne, A. J., Pritchard, H., Rignot, E., Rott, H., Sandberg Sørensen, L., Scambos, T. A., Scheuchl, B., Schrama, E. J. O., Smith, B., Sundal, A. V., van Angelen, J. H., van de Berg, W. J., van den Broeke, M. R., Vaughan, D. G., Velicogna, I., Wahr, J., Whitehouse, P. L., Wingham, D. J., Yi, D., Young, D., and Zwally, H. J.: A reconciled estimate of ice-sheet mass balance, Science, 338, 1183-1189, doi:10.1126/science.1228102 2012.

Smeets, C. J. P. P. and van den Broeke, M. R.: Temporal and spatial variations of the aerodynamic roughness length in the ablation zone of the Greenland ice sheet, Bound.-Lay. Meteorol., 128, 315-338, doi:10.1007/s10546-008-9291-0, 2008.

Solomon, S., Qin, D., Manning, M., Chen, Z., Marquis, M., Averyt, K. B., Tignor, M., and Miller, H. L. (Eds.): IPCC, Climate Change 2007: The Physical Science Basis, in: Contribution of Working Group I to the Fourth Assessment Report of the Intergovernmental Panel on Climate Change Cambridge University Press, Cambridge, UK and New York, NY, USA, 996 pp., 2007.

Sturm, M., Holmgren, J., Köning, M., and Morris, K.: The thermal conductivity of seasonal snow, J. Glaciol., 43, 26-41, 1997.

Tedesco, M., Fettweis, X., van den Broeke, M. R., van de Wal, R. S. W., Smeets, C. J. P. P., van de Berg, W. J., Serreze, M. C., and Box, J. E.: The role of albedo and accumulation in the 2010 melting record in Greenland, Environ. Res. Lett., 6, 014005, doi:10.1088/1748-9326/6/1/014005, 2011.

Tedesco, M., Fettweis, X., Mote, T., Wahr, J., Alexander, P., Box, J. E., and Wouters, B.: Evidence and analysis of 2012 Greenland records from spaceborne observations, a regional climate model and reanalysis data, The Cryosphere, 7, 615-630, doi:10.5194/tc7-615-2013, 2013.

Van Angelen, J. H., van den Broeke, M. R., and van de Berg, W. J.: Momentum budget of the atmospheric boundary layer over the Greenland ice sheet and its surrounding seas, J. Geophys. Res.Atmos., 116, D10101, doi:10.1029/2010JD015485, 2011.

Van Angelen, J. H., Lenaerts, J. T. M., van den Broeke, M. R., Fettweis, X., and Meijgaard, E.: Rapid loss of firn pore space accelerates 21 st century Greenland mass loss, Geophys. Res. Lett., 40, 2109-2113, doi:10.1002/grl.50490, 2013.

Van As, D.: Warming, glacier melt and surface energy budget from weather station observations in the Melville Bay region of northwest Greenland, J. Glaciol., 57, 208-220, doi:10.3189/002214311796405898, 2011.

Van As, D., van den Broeke, M. R., Reijmer, C. H., and van de Wal, R. S. W.: The summer surface energy balance of the high Antarctic plateau, Bound.-Lay. Meteorol., 115, 289-317, doi:10.1007/s10546-004-4631-1, 2005. 
Van As, D., Hubbard, A. L., Hasholt, B., Mikkelsen, A. B., van den Broeke, M. R., and Fausto, R. S.: Large surface melt water discharge from the Kangerlussuaq sector of the Greenland ice sheet during the record-warm year 2010 explained by detailed energy balance observations, The Cryosphere, 6, 199-209, doi:10.5194/tc-6-199-2012, 2012.

Van As, D., Fausto, R. S., Colgan, W. T., Box, J. E., and the PROMICE project team: Darkening of the Greenland ice sheet due to the melt-albedo feedback observed at the PROMICE weather stations, Geol. Surv. Denmark Greenland Bull., 28, 6972, 2013.

Van As, D., Fausto, R. S., Steffen, K., and the PROMICE project team: Katabatic winds and piteraq storms: observations from the Greenland ice sheet, Geol. Surv. Denmark Greenland Bull., 31, 83-86, 2014.

Van den Broeke, M. R., van As, D., Reijmer, C. H., and van de Wal, R. S. W.: Assessing and Improving the Quality of Unattended Radiation Observations in Antarctica, J. Atmos. Ocean. Tech., 21, 1417-1431, doi:10.1175/15200426(2004)021<1417:AAITQO>2.0.CO;2, 2004.

Van den Broeke, M. R., Smeets, C. J. P. P., Ettema, J., and Kuipers Munneke, P.: Surface radiation balance in the ablation zone of the west Greenland ice sheet, J. Geophys. Res.-Atmos., 113, D13105, doi:10.1029/2007JD009283, 2008a.

Van den Broeke, M. R., Smeets, C. J. P. P., Ettema, J., van der Veen, C., van de Wal, R. S. W., and Oerlemans, J.: Partitioning of melt energy and melt water fluxes in the ablation zone of the west Greenland ice sheet, The Cryosphere, 2, 179-189, doi:10.5194/tc-2-179-2008, 2008b.

Van den Broeke, M. R., Smeets, C. J. P. P., and Ettema, J.: Surface layer climate and turbulent exchange in the ablation zone of the west Greenland ice sheet, Int. J. Climatol., 29, 2309-2323, doi:10.1002/joc.1815, 2009.

Van den Broeke, M. R., Smeets, C. J. P. P., and van de Wal, R. S. W.: The seasonal cycle and interannual variability of surface energy balance and melt in the ablation zone of the west Greenland ice sheet, The Cryosphere, 5, 377-390, doi:10.5194/tc-5-377-2011, 2011.

Van de Wal, R. S. W., Bintanja, R., Boot, W., van den Broeke, M. R., Conrads, L. A., Duynkerke, P. G., Fortuin, P., Henneken, E. A. C., Knap, W. H. L., Portanger, M., Vugts, H. F., and Oerlemans, J.: Mass balance measurements in the Søndre Strømfjord area in the period 1990-1994, Z. Gletscherkd. Glazialgeol., 31, 57-63, 1995.
Van de Wal, R. S. W., Greuell, W., van den Broeke, M. R., Reijmer, C. H., and Oerlemans, J.: Surface mass-balance observations and automatic weather station data along a transect near Kangerlussuaq, Greenland, Ann. Glaciol., 42, 311-316, doi:10.3189/172756405781812529, 2005.

Van de Wal, R. S. W., Boot, W., Smeets, C. J. P. P., Snellen, H., van den Broeke, M. R., and Oerlemans, J.: Twenty-one years of mass balance observations along the K-transect, west Greenland, Earth Syst. Sci. Data, 4, 31-35, doi:10.5194/essd-4-31-2012, 2012.

Vaughan, D. G., Comiso, J. C., Allison, I., Carrasco, J., Kaser, G., Kwok, R., Mote, P., Murray, T., Paul, F., Ren, J., Rignot, E., Solomina, O., Steffen, K., and Zhang, T.: Observations: Cryosphere, in: Climate Change 2013: The Physical Science Basis, Contribution of Working Group I to the Fifth Assessment Report of the Intergovernmental Panel on Climate Change, edited by: Stocker, T. F., Qin, D., Plattner, G.-K., Tignor, M., Allen, S. K., Boschung, J., Nauels, A., Xia, Y., Bex, V., and Midgley, P. M., Cambridge University Press, Cambridge, UK and New York, NY, USA, 2013.

Vernon, C. L., Bamber, J. L., Box, J. E., van den Broeke, M. R., Fettweis, X., Hanna, E., and Huybrechts, P.: Surface mass balance model intercomparison for the Greenland ice sheet, The Cryosphere, 7, 599-614, doi:10.5194/tc-7-599-2013, 2013.

Wang, D. D., Morton, D., Masek, J., Wu, A. A., Nagol, J., Xiong, X., Levy, R., Vermote, E., and Wolfe, R.: Impact of sensor degradation on the MODIS NDVI time series, Remote Sens. Environ., 119, 55-61, doi:10.1016/j.rse.2011.12.001, 2012.

Wientjes, I. G. M. and Oerlemans, J.: An explanation for the dark region in the western melt zone of the Greenland ice sheet, The Cryosphere, 4, 261-268, doi:10.5194/tc-4-261-2010, 2010.

Yen, Y. C.: Review of thermal properties of snow, ice and sea ice. Technical report, Vol. 81, CRREL Report, US Army Corps of Engineers, Cold Regions Research and Engineering Laboratory, Hanover, New Hampshire, USA, 27 pp., 1981. 